\title{
Late spring phytoplankton bloom in the Lower St. Lawrence Estuary: the flushing hypothesis revisited
}

\author{
Bruno A. Zakardjian ${ }^{1, *}$, Yves Gratton ${ }^{2}$, Alain F. Vézina ${ }^{3, * *}$ \\ 'Institut des Sciences de la Mer de Rimouski, 310, allée des Ursulines, Rimouski, Québec G5L 3A1, Canada \\ ${ }^{2}$ Institut national de la recherche scientifique-Eau, 2800, rue Einstein, Case Postale 7500, Sainte-Foy, Québec G1V 4C7, Canada \\ ${ }^{3}$ Pêches et Océans Canada, Institut Maurice Lamontagne, 850, route de la Mer, PO Box 1000, Mont-Joli, Québec G5H 3Z4, Canada
}

\begin{abstract}
In the Lower St. Lawrence Estuary (LSLE), environmental conditions (stratification, surface light and nutrients) are favorable for phytoplankton growth starting in May, but the spring phytoplankton bloom typically does not occur until early summer (late June-July). Possible explanations for the late onset of the phytoplankton bloom include flushing of the surface layer due to the spring freshwater runoff, loss of phytoplankton cells from the thin euphotic layer through sinking and mixing, and temperature limitation of phytoplankton growth rates. We use 1- and 2-D time-dependent models of phytoplankton dynamics to explore these hypotheses. In particular, we illustrate the role of (1) phytoplankton cell sinking versus vertical turbulent mixing and (2) flushing of freshwater runoff on primary production in the LSLE. Results of the 1-D simulations show the dramatic effect of phytoplankton cell sinking in a thin euphotic zone, while at the same time high vertical turbulent mixing may act to maintain these sinking phytoplankton cells in the euphotic layer. Nevertheless, the 1-D analysis cannot account for spatio-temporal patterns in the development of the phytoplankton bloom observed during a high resolution physical, chemical and biological sampling field experiment performed in the summer of 1990 in the LSLE. 2-D simulations, run with seaward advective velocities in the range 0.15 to $0.3 \mathrm{~m}$ $\mathrm{s}^{-1}$, close to observed values, generate downstream patterns of phytoplankton biomass that resemble these observed pattems. Comparison with observations helps to specify the range of sinking and advective velocities that operate in concert to control the timing and spatial location of the bloom.
\end{abstract}

KEY WORDS: Phytoplankton bloom · Physical-biological coupling · Vertical turbulent mixing · Sinking Flushing rates $\cdot$ St. Lawrence Estuary

\section{INTRODUCTION}

The Lower St. Lawrence Estuary (LSLE; Fig. 1) is a wide $(30$ to $50 \mathrm{~km})$ and deep $(300 \mathrm{~m})$ estuary at the maritime end of a large $(400 \mathrm{~km}$ long) and complex hydrodynamic system known as the St. Lawrence Estuary. The LSLE's main feature is the $300 \mathrm{~m}$ deep Laurentian Trough intruding from the Atlantic Ocean and ending abruptly at its head near Tadoussac, where the depth reduces from 300 to $50 \mathrm{~m}$ over less than

\footnotetext{
-E-mail: bruno_zakardjian@uquar.uquebec.ca

- Present address: Bedford Institute of Oceanography,

PO Box 1000, Dartmouth, Nova Scotia B27 A42, Canada

$20 \mathrm{~km}$. The high freshwater discharges from the St. Lawrence and Saguenay rivers (18 to $24 \times 10^{3} \mathrm{~m}^{3} \mathrm{~s}^{-1}$ ), coupled with active mixing at the confluence of these rivers at the head of the Laurentian Channel, lead to the continuous creation of a light water mass. Due to the width of the LSLE, which is several local internal Rossby deformation radii, this light water mass is subjected to geostrophic adjustment and the estuarine induced seaward flow takes the form of a jet-like structure that follows the south shore and amplifies downstream as the Gaspé current (Mertz et al. 1988). Physical conditions are also strongly dependent on atmospheric events at synoptic or seasonal time scales (Koutitonsky \& Bugden 1991, Mertz et al. 1992) but it is 
$70^{\circ} \mathrm{W} \quad 65^{\circ} \mathrm{W} \quad 60^{\circ} \mathrm{W}$

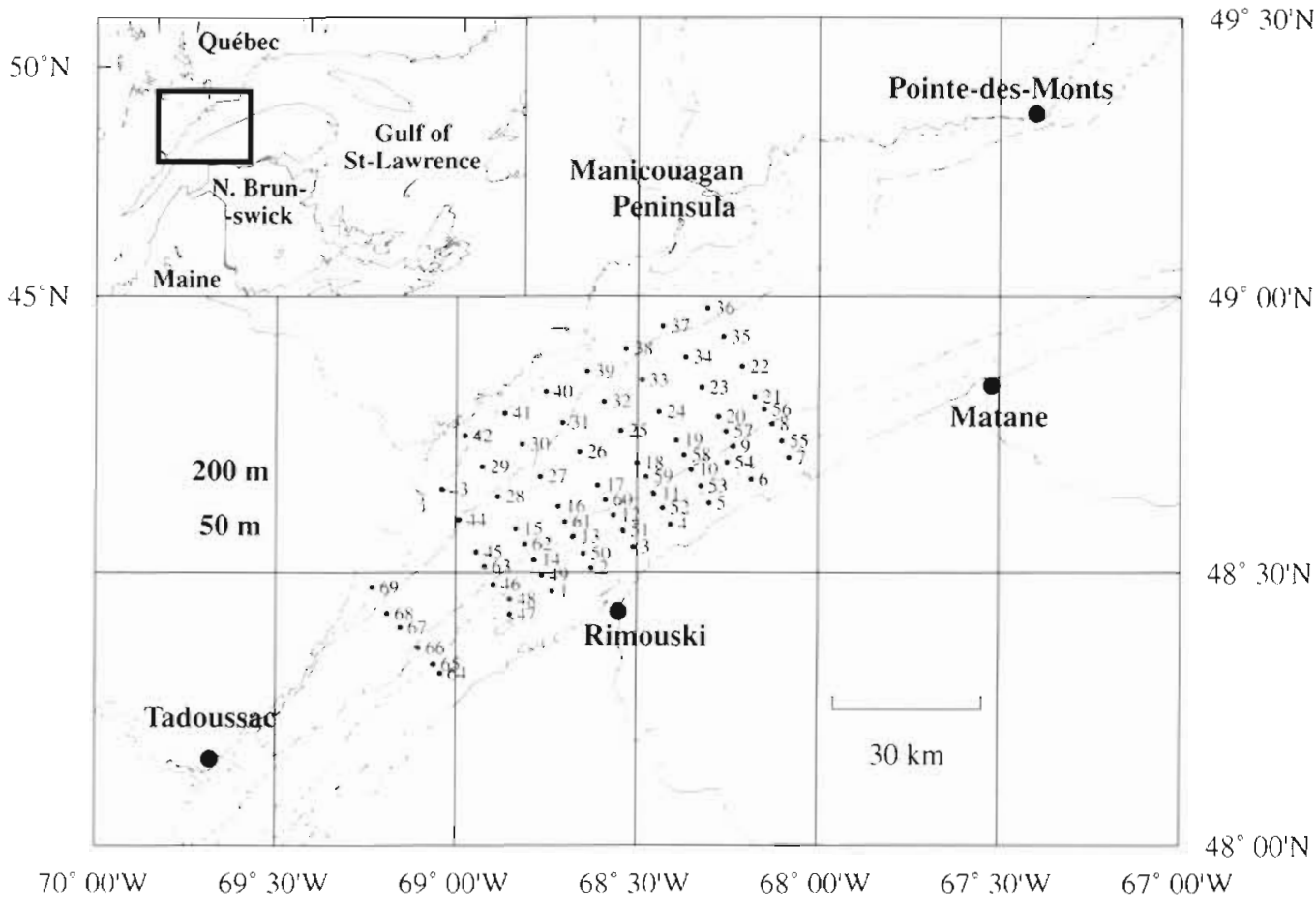

Fig. 1. Geographical location and detalled map of the Lower St. Lawrence Estuary. Dashed lines: 50 and $200 \mathrm{~m}$ isobaths, showing the location of the Laurentian Channel and extension of the shelf. Also shown are the locations of the physical and biological sampling stations of the COUPPB-90 experiment now assumed that this buoyancy-induced circulation dominates the physics of the LSLE (Ingram \& El-Sabh 1990, Koutitonsky \& Bugden 1991.).

These hydrodynamic conditions show a strong spatio-temporal. variability that leads to marked variability in primary and secondary production (e.g. Therriault et al. 1990, de Lafontaine et al. 1991, Vézina 1994). Sporadic blooms of toxic algae (Alexandrium sp.) in the LSLE or in the Gaspé current may be due to particLlar hydrodynamic conditions (Therriault et al. 1985). Higher phytoplankton productivity or local zooplankton aggregations (Runge \& Simard 1990) occur in relation to several types of oceanic fronts (Ingram \& ElSabh 1990). Studies of the coupling between physical and biological processes in the estuary and gulf are needed in order to understand the dynamics of harmful algae blooms and the carbon cycle, as well as the constraints on secondary and fish production in the region.

The spring phytoplankton bloom, a general feature in high and moderate latitudes, typically occurs in early summer (late june-july) in the LSLE even though environmental conditions (surface stratification, high light and nutrient concentrations) are favorable for phytopluntoton giowth in May, 4 to 8 wh carlice (c.g. Levasseur et al. 1984). The factors responsible for this delay are not well understood but are likely to be hydrodynamic Many authors believe that the major features of the temporal (seasonal as well as synoptic time scales) distribution of phytoplankton biomass and production in estuaries and shelves is predominantly related to physical processes (e.g. Pingree 1978, Malone et al. 1980. Sinclair et al. 1981, Powell et al. 1989, Lucas et al. 1998).

In this study, we use 1- and 2-D time-dependent models of phytoplankton dynamics to evaluate the relative roles of (1) vertical turbulent mixing versus phytoplankton cell sinking and (2) seaward advective transport associated with the freshwater runoff in determining the timing of this late spring phytoplankton bloom. The formulation and initialization of the models are defined with regards to physical, chemical and biological data obtained during the COUPPB-90 (COUPlage entre les processus Physiques et Biogeochimiques) mesoscale field experiment which covered the early summer 1990 bloom period (Savenkoff et al. 1997). By comparison with the COL PPB-90 data set, we show here that advective velocities in the LSLE and low sinking rates are consistent with tho observed spatio-temporal patterns in the development of the phytoplankton bloom. This allows us to specify the range of sinking and advective velocities that operate in concert to control the timing and spatial location of the bloom.

\section{FORMULATION OF THE MODELS}

Background and working hypothesis. The numerical tool presented here is a process model which uses mean biological parameters found in the literature and focuses on the effect of physical processes on phyto- 
plankton production. The simulations do not attempt to reproduce any particular event in the LSLE but attempt to capture the general conditions that affect bloom formation in the LSLE in order to explain its delay. The impact of short-term (less than $1 \mathrm{~d}$ ) variability in the environmental conditions (semi-diurnal tidal mixing, diurnal light cycle) on the phytoplankton dynamics is not considered in this study. We assume that population development is more likely to depend on ecological conditions averaged over time scales greater than typical doubling times of phytoplankton cells (i.e. more than 1 d, see Zakardjian \& Prieur 1994).

Likewise, the simulations do not take into account self-shading processes, which are not believed to impede the first stage of the bloom, hence the timing of the bloom. Assuming stationary physical forcinglight, vertical turbulent mixing and seaward advection - the time-dependent vertical distribution of phytoplankton biomass $(B)$, nitrate $\left(\mathrm{NO}_{3}\right)$ and ammonium $\left(\mathrm{NH}_{4}\right)$ concentrations are computed from the set of differential equations given in Table 1. Physical forcing processes (vertical turbulent mixing and advection) were defined from observations made during the
COUPPB-90 mesoscale field experiments (see next section). Phytoplankton growth rate $(\mu)$ is formulated with a Liebig-type formulation (Eq. 7), assuming a hyperbolic saturation curve for photosynthesis (Eq. 9a) and using the O'Neill et al. (1989) substitutable model for nitrate and ammonium assimilation (Eq. 8b). Respiration is not explicitely included in the modeli instead it can be considered to be a fraction of $\mu_{\max }$ (e.g. Prieur \& Legendre 1988), as it may be of little importance in initiating bloom development (Smetacek \& Passow 1990).

The dynamics of micra- and mesozooplankton populations is not believed to affect the timing or the development of the bloom. Plourde \& Runge (1993) have shown that the timing of final maturation and the spawning event of Calanus finmarchicus, a dominant copepod species in the LSLE, is strongly linked with the timing of the bloom. Grazing pressure from this population increases after the beginning of the spawning event, which proceeds throughout the summer, concurrent with relatively high phytoplankton biomass in the LSLE (e.g. Levasseur et al. 1984, Plourde \& Runge 1993). While ciliated protozoans may play a

Table 1. System of differential equations used to simulate the spatial and temporal evolution of the state variables. The symbols are defined in Table 2

$$
\begin{aligned}
& \frac{\partial B}{\partial t}+\nabla(\vec{U} \quad B)=\nabla\left(K_{D} \nabla B\right)+\mu B-\operatorname{Graz}(B)+\frac{\partial}{\partial z}\left(w_{\mathrm{s}} B\right) \\
& \frac{\partial \mathrm{NO}_{3}}{\partial t}+\nabla\left(\bar{U} \cdot \mathrm{NO}_{3}\right)=\nabla\left(K_{\mathrm{D}} \nabla \mathrm{NO}_{3}\right)-S_{\mathrm{NO}_{3}} \mu B \\
& \frac{\partial \mathrm{NH}_{4}}{\partial t}+\nabla\left(\bar{U} \mathrm{NH}_{4}\right)=\nabla\left(K_{\mathrm{D}} \cdot \nabla \mathrm{NH}_{4}\right)-S_{\mathrm{NH}_{4}} \mu B+\operatorname{Reg} \cdot \operatorname{Graz} .(B) \\
& \text { Exp. }=\int_{z=0}^{z b}(1-\text { Reg. }) \operatorname{Graz} \cdot(B) \delta z \\
& \operatorname{Graz}(B)=\bar{Z} G_{\max }\left\{1-\exp \left[\beta\left(B-S_{\mathrm{b}}\right)\right]\right\} H\left(B, S_{\mathrm{b}}\right) \\
& t_{\mathrm{s}}=\frac{t_{\mathrm{d} \text { min }}}{f[N]} \\
& S_{\mathrm{NO}_{3}}=\frac{\mathrm{NO}_{3} K_{\mathrm{NH}_{4}}}{\mathrm{NO}_{3} K_{\mathrm{NH}_{4}}+\mathrm{NH}_{4} K_{\mathrm{NO}_{3}}} \\
& t_{\mathrm{c}}=t_{\mathrm{d} \min }\left(1+\frac{K_{\mathrm{E}}}{E}\right) \\
& K_{z}=0.25 \frac{\varepsilon}{N^{2}}
\end{aligned}
$$


Table 2. List of symbol and values of constants used in the simulations (Var. denotes variables calculated by the model as opposed to imposed variables and parameters). PAR: photosynthetically active radiation

\begin{tabular}{|c|c|c|}
\hline Symbol & Value/units & Definition \\
\hline$B$ & Var. $\mathrm{mmol} \mathrm{N} \mathrm{m}^{-3}$ & Phytoplankton biomass in terms of nitrogen \\
\hline$\beta$ & $0.35 \mathrm{mmol} \mathrm{N} \mathrm{N}^{-1} \mathrm{~m}^{3}$ & Ingestion coefficient for the Ivlev-type grazing function \\
\hline$x$ & $0.3 \mathrm{~m}^{-1}$ & Light extinction coefficient \\
\hline$\delta t$ & $1.0 \mathrm{~h}$ & Time step of the simulation \\
\hline$\delta x$ & $5 \mathrm{~km}$ & Horizontal increment of the 2-D Eulerian grid \\
\hline$\delta z$ & $1.0 \mathrm{~m}$ & Vertical increment of the Eulerian grid \\
\hline$E$ & Ein $\mathrm{m}^{-2} \mathrm{~d}^{-1}$ & Mean daily available PAR at each depth \\
\hline$E_{0}$ & 30.0 Ein $\mathrm{m}^{-2} \mathrm{~d}^{-1}$ & Mean daily surface irradiance (PAR) \\
\hline Exp. & Var. mmol $\mathrm{N} \mathrm{m}^{-2} \mathrm{~d}^{-1}$ & Biologically exported organic matter \\
\hline$\varepsilon$ & $0.5-5.010^{-7} \mathrm{~m}^{2} \mathrm{~s}^{-3}$ & Dissipation rate of turbulent kinetic energy \\
\hline$G_{\text {max }}$ & $0.5 d^{-1}$ & Maximum grazing rate for the Ivlev-type functiond \\
\hline $\operatorname{Graz}(B)$ & Var. mmol $\mathrm{N} \mathrm{m}^{-3} \mathrm{~d}^{-1}$ & Ivlev-type grazing function \\
\hline$H\left(B, S_{\mathrm{b}}\right)$ & Var, dimensionless & Heavyside function associated with the feeding threshold \\
\hline$K_{0}$ & $m^{2} d^{-1}$ & General 3-D diffusivity tensor \\
\hline$K_{z}$ & $m^{2} d^{-1}$ & Vertical turbulent diffusivity coefficient \\
\hline$K_{\mathrm{E}}$ & 10.0 Ein $\mathrm{m}^{-2} \mathrm{~d}^{-1}$ & Half saturation constant for the light versus photosynthesis relationship \\
\hline$K_{\mathrm{NH}_{4}}$ & $0.1 \mathrm{mmol} \mathrm{m}^{-3}$ & Half saturation constant for the Michaelis-Menten kinetics of $\mathrm{NH}_{4}$ uptake \\
\hline$K_{\text {vo }}$ & $0.5 \mathrm{mmol} \mathrm{m}^{-3}$ & Half saturation constant for the Michaelis-Menten kinetics of $\mathrm{NO}_{3}$ uptake \\
\hline$\mu$ & Var. $d^{-1}$ & Phytoplankton growth rate \\
\hline$N$ & $\mathrm{~s}^{-1}$ & Brunt-Väisälä frequency \\
\hline $\mathrm{NH}_{4}$ & Var. $\mathrm{mmol} \mathrm{Nm}^{-3}$ & Ammonium concentration \\
\hline $\mathrm{NO}_{3}$ & Var. $\mathrm{mmol} \mathrm{Nm}^{-3}$ & Nitrate concentration \\
\hline Reg. & 0.4 , dimensionless & Fraction of grazed nitrogen which is excreted by zooplankton as $\mathrm{NH}_{4}$ \\
\hline$S_{\mathrm{b}}$ & $0.1 \mathrm{mmol} \mathrm{N} \mathrm{m}^{-3}$ & Feeding threshold for the Ivlev-type grazing function \\
\hline$S_{\mathrm{NH}_{4}}$ & Var., dimensionless & Fraction of phytoplankton growth sustained by $\mathrm{NH}_{4}$ \\
\hline$S_{\text {No }}$ & Var., dimensionless & Fraction of phytoplankton growth sustained by $\mathrm{NO}_{3}$ \\
\hline$t_{c}$ & Var. d & Phytoplankton doubling time in carbon biomass \\
\hline$t_{\text {crit }}$ & $8.4 \mathrm{~d}$ & Maximum phytoplankton doubling time: if $t_{c}(z)$ or $t_{s}\left(z_{1} t\right)>t_{\mathrm{cn}}$, then $\mu(z, t)=0$ \\
\hline$t_{\mathrm{d} \min }$ & $0.5 \mathrm{~d}$ & Minimum phytoplankton doubling time \\
\hline$t_{\mathrm{s}}$ & Var. d & Phytoplankton doubling time in nitrogen biomass \\
\hline$U$ & $\mathrm{~ms}^{-1}$ & General 3-D velocity vector \\
\hline$U, U_{\text {mes }}$ & $\mathrm{m} \mathrm{s}^{-1}$ & Measured along-estuary current velocity \\
\hline$U_{\sigma}$ & $\mathrm{m} \mathrm{s}^{-1}$ & Surface current velocity \\
\hline$w_{3}$ & $0-3 \mathrm{~m} \mathrm{~d}^{-1}$ & Sinking rate of phytoplankton cells \\
\hline $\bar{z}^{s}$ & $1.2 \mathrm{mmol} \mathrm{N} \mathrm{m}^{-3}$ & Mean grazer zooplankton biomass \\
\hline
\end{tabular}

major role in the trophic links between phytoplankton and mesozooplankton in the LSLE, it is unlikely that they impede the development of the bloom (c.g. SimeNgando et al. 1995). In the model, grazing pressure (Graz.) is simply defined by an Ivlev-type function (Eq. 6), assuming a mean constant grazer biomass (meso- and microzooplankton) taken from the literature (see references at the bottom of Table 2) for ILSLE and Eastern Canadian waters in late spring/early summer. This means zooplankton biomass was unable to provent the diatom blocin or a 2 fold higher biomass, as described later.

To take into account nitrogen regeneration, a constant fraction (0.4) of the grazed phytoplankton nitrogen is regenerated in terms of ammonium (e.g. Frost 1980, Kibrboe 1989). The fraction of grazed and nonregenerated nitrogen is taken as exported production.
(Exp. in Eq. 4, Table 1). Nutrients and phytoplankton biomass are computed in mmol $\mathrm{N} \mathrm{m}^{-3}$ Phytoplankton biomass and production terms are then converted to $\mathrm{mg}$ chl $a \mathrm{~m}^{-3}$ and $\mathrm{mg} \mathrm{C} \mathrm{m}^{-3} \mathrm{~d}^{-1}$, respectively, to facilitate comparisons with field data. Conversion in terms of carbon is made through the Redfield molar ratio $106 / 16$ for $\mathrm{C} / \mathrm{N}$ and for chl $a$ using the weight ratio $1 / 80$ for chl $a / C$, which would be representative of the diatom population in the pre- and early bloom period (mainly Nitzschia sp, see Sime-Ngando et al. 1995).

The range of sinking iutes tosted in the simulations is 0 to $3 \mathrm{~m} \mathrm{~d}^{-1}$, typical of individual sinking diatoms (Smayda 1970). Diatom chains may sink faster and flocculation of diatom blooms can lead to sinking of aggregated growing cells at speeds of several tens of meters per day (Alldredge \& Jackson 1995). We assumed, however, that the coupled flocculation and 
aggregation processes are of little importance in the early stage of the bloom, hence for its timing, but may play a major role in the later stages of the bloom (e.g. Jackson \& Lochman 1992).

Physical processes: the COUPPB-90 data set. The COUPPB-90 experiment consisted of 3 consecutive cruises (Legs G2, G3 and G4) that covered the 50 station grid shown in Fig. 1 each day for 3 d. The experiment was conducted between 30 June and 9 July and covered half a neap-spring tidal cycle (from neap to spring). At each station, sampling included temperature, salinity, oxygen and turbidity profiles (surface to 5 to $10 \mathrm{~m}$ off bottom) from an Applied Microsystem STD-12; vertical profiles of horizontal currents from a $150 \mathrm{kHz}$ Acoustic Doppler Current Profiler (ADCP); and 0 to $30 \mathrm{~m}$ continuous profiles of photosynthetic pigments (in vivo fluorescence of chl a) and nutrients (nitrate and silicate). Several additional biogeochemical and physical measurements were conducted at 3 stations located in the Laurentian Trough. In addition, Aanderaa current meters were moored at 7 locations between May and September. Details of these experiments can be found in Savenkoff et al. (1997) and Marsden \& Gratton (1998).

Briefly, this study showed that, in 1990, the onset of the late spring phytoplankton bloom in the LSLE is related to the formation of transverse currents generated by geostrophic adjustments during the passage of freshwater pulses originating from the head of the Laurentian Channel. Conditions prior to the bloom featured a well-defined, along-shore alignment of thermohaline properties and a prominent seaward residual current. The switch from this prevailing situation to the transverse current configuration took place in a short time, i.e. 3 to $5 \mathrm{~d}$. The circulation patterns after the passage of these pulses showed complex features at various scales (small to mesoscale) that superseded the conspicuous seaward residual currents previously observed. The stratification of the euphotic layer $(12 \mathrm{~m}$ depth) increased from Legs G2 to G4 as the result of a decrease in salinity in the upper layer due to the passage of the freshwater pulse through the study area (Savenkoff et al. 1997). Objective analysis has shown that the observed physical and biological structures were unrelated to the phases of the semi-diurnal tidal cycle. Detailed presentation and discussion of these results can be found in Savenkoff et al. (1997).

In each simulation, the vertical diffusion coefficient $K_{z}$ was estimated from the mean Brunt-Väisälä frequency profile $(N$ ) from Leg G2 (Fig. 2a,b) using the Osborn (1980) formulation (Eq. 10, Table 1). The mean $N$ profile was calculated as a Chebyshev interpolation of the complete Leg G2 data set using the trend1d routine of the GMT package (Generic Mapping Tools, Wessel \& Smith 1991), as for all other Chebyshev inter-

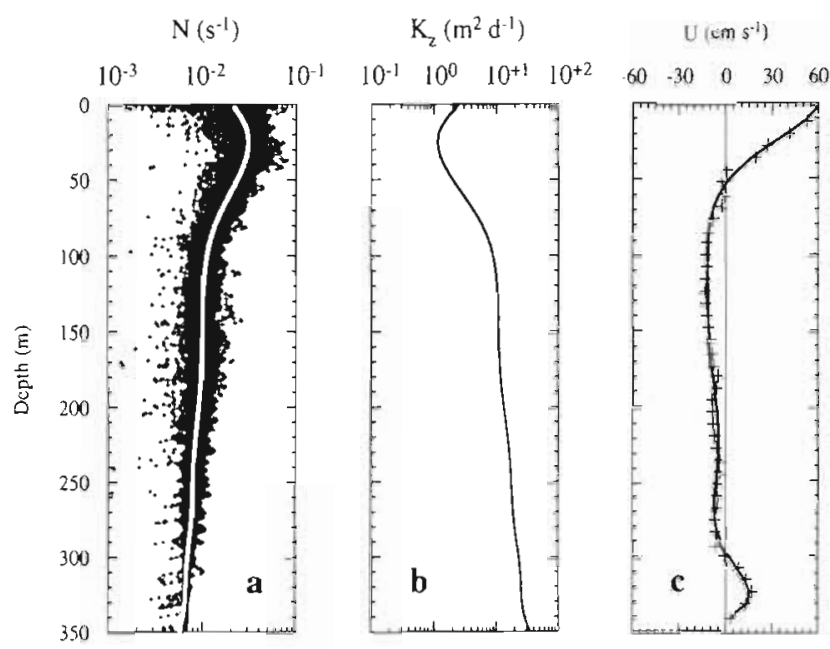

Fig. 2. Physical conditions used in the simulations: (a) vertical distributions of observed Brunt-Väisälä frequencies $(N)$ during Leg G2 and the Chebyshev polynomial used in the simulations to define the mean stratification (solid line); (b) eddy diffusion coefficient $\left(K_{z}\right)$ calculated from the mean stratification with a turbulent kinetic energy (TKE) dissipation rate $(\varepsilon)$ of $5.0 \times 10^{-8} \mathrm{~m}^{3} \mathrm{~s}^{-1}$; (c) Acoustic Doppler Current Profiler measured vertical profile of the along-channel baroclinic velocity $(U)$ obtained at Stn 23 during Leg $G 2(+)$ and the fitted Chebyshev polynomial used in the simulations (solid line)

polations in this study. This mean $N$ profile is considered to be representative of the pre-bloom stratification conditions

In the LSLE, the head of the Laurentian Channel is an active zone of mixing where high turbulent mixing rates are due to the large shear associated with the generation of internal tides or travelling solitons, both being detectable as far as $100 \mathrm{~km}$ downstream of the generation area (e.g. Forrester 1974, Galbraith 1992). While these high turbulent mixing rates are typical of the particular hydrodynamic conditions at the head of the Laurentian Channel, we can expect similar, but attenuated, mixing processes over a large part of the LSLE (Gratton et al. 1988). We used different values for the turbulent kinetic energy (TKE) dissipation rate $\left(\varepsilon=5.0 \times 10^{-8}\right.$ to $5.0 \times 10^{-7} \mathrm{~m}^{2} \mathrm{~s}^{-3}$ ) to define several vertical turbulent mixing regimes for this single $N$ profile. These are test simulations that do not consider the response of stratification to the imposed mixing.

Current velocities used in the 2 -D model are derived from a Chebyshev interpolation of the baroclinic velocities (ADCP measured minus vertical mean) at Stn 23 (Fig. 2c) during Leg G2. We selected this station because it showed the highest seaward surface velocity $\left(0.6 \mathrm{~m} \mathrm{~s}^{-1}\right)$ and surface baroclinicity $\left(0.6 \mathrm{~m} \mathrm{~s}^{-1}\right.$ over $\left.50 \mathrm{~m}\right)$. Stn 23 was visited during high tide slack water during Leg G2. Strong baroclinicity in the euphotic layer may have a marked effect on the vertical distributions of chl $a$, nutrients and dissolved oxygen (Savenkoff et al. 
1997). Note that below $50 \mathrm{~m}$, the current reverses and flows slowly upstream. Analogous to the classical estuarine circulation, this 2-layer circulation in the Laurentian Trough is typical of the LSLE (e.g. El-Sabh 1979, Koutitonsky \& Bugden 1991).

Nevertheless, the high surface baroclinic velocities at Stn 23 are the result of a point measurement and may not be representative of the mean residual seaward advection of the buoyancy-induced circulation. They represent rather an upper bound to the associated surface current. The seaward, buoyancy-induced circulation in the LSLE in late spring shows residual currents of the order $0.3 \mathrm{~m} \mathrm{~s}^{-1}$ (e.g. El-Sabh 1979, Mertz et al. 1988). Other 2-D simulations made with values one-half to a quarter of the values in the measured baroclinic velocity profile at Stn 23 were assumed to be more typical of the seaward residual component of the springtime buoyancy-induced circulation in the LSLE.

Numerical techniques. Numerical techniques are already described in Zakardjian \& Prieur (1994) and are briefly reviewed here. Both models extend vertically to $150 \mathrm{~m}$ and the $2-\mathrm{D}$ version has a horizontal domain of $200 \mathrm{~km}$ (approximately from the head of the Laurentian Channel, near Tadoussac, to Pointe-desMonts; see Fig. 1). Except for phytoplankton nitrogen, initial conditions are defined as the Chebyshev interpolations of vertical distributions observed during the COUPPB-90 experiment. For nitrate and ammonium we used the complete sets of vertical distributions (Stns 23, 26 and 67 and Legs G2 to G4) from bottle casts (Fig. 3). The initial phytoplankton nitrogen vertical distribution represents a constant low phytoplankton biomass ( $0.6 \mathrm{mmol} \mathrm{N} \mathrm{m}^{-3}$ ) over the first $30 \mathrm{~m}$, decreasing exponentially below this.

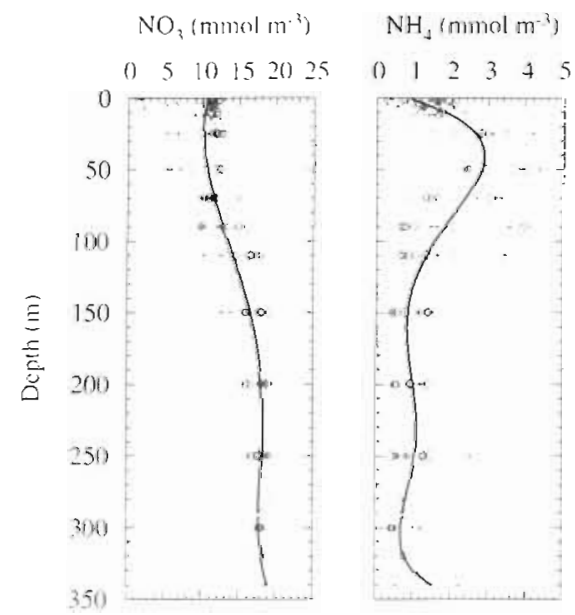

Fig. 3. Vertical profiles used as initial and lateral boundary conditions for nitrate $\left(\mathrm{NO}_{3}\right)$ and ammonium $\left(\mathrm{NH}_{4}\right)$. Solid lines: Chebyshev polynomials fitted to observed values for the 3 legs, $\mathrm{G} 2$ to 4 (0: $\operatorname{Stn} 67,+: \operatorname{Stn} 23,0: \operatorname{Stn} 26)$
Vertical boundary conditions are: no fluxes at the sea surface (Neuman condition with vertical derivatives set to zero for all variables) and constant concentrations (Dirichlet condition), for the bottom boundary. Constant concentrations at the bottom are calculated from the Chebyshev polynomials at $150 \mathrm{~m}$ depth. Upstream and downstream boundaries in the 2-D model are open (Dirichlet conditions), with constant vertical distributions as the initial conditions. Observations made during the COUPPB-90 experiment were consistent with time-independent upstream conditions. The downstream boundary conditions have no impact on the simulations because the flow in the surface layer is downstream.

We solved the set of differential equations Eqs. (1) to (4) (Table 1) in a discrete form (semi-implicit CrankNicolson scheme derived from the Control Volume Approach, see Roach 1972) with Choleski's double scanning method (also called Thomas algorithm in Roach 1972) in an iterative form (because of the nonlinear grazing and phytoplankton growth terms) and with the method of alternate directions in the 2-D model.

\section{RESULTS}

\section{The standard simulation as an illustration of a classical spring bloom}

The standard $60 \mathrm{~d}$ simulation using parameters found in the literature (see Table 2), non-sinking phytoplankton and a low value for the TKE dissipation rate $\left(\varepsilon=5.0 \times 10^{-8} \mathrm{~m}^{2} \mathrm{~s}^{-3}\right)$ led to a strong bloom that appears first as a rapid increase in depth-integrated phytoplankton biomass and primary production (Fig. 4a) within the first $5 \mathrm{~d}$. Maximum values of ca $2.2 \mathrm{~g} \mathrm{C} \mathrm{m}^{-2} \mathrm{~d}^{-1}$ for primary production and $110 \mathrm{mg} \mathrm{chl} \mathrm{a} \mathrm{m}^{-2}$ for phytoplankton biomass were reached at Days 5 and 13 respectively. In the surface layer, chl a concentrations

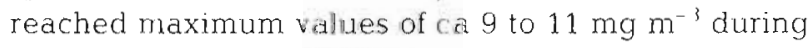
the bloom and the phytoplankton exhausted surface nitrogen nutrient (nitrates and ammonium in the first 5 $\mathrm{m}$ ) after less than $5 \mathrm{~d}$. Later, grazing acted to decrease phytoplankton nitrogen and the system slowly tended to a steady state with a slight deep chlorophyll maximum (DCM) which developed from the deepening nutricline down to the bottom of the euphotic zone. After 60 d, the depth-integrated phytoplunkton nitrogen and primary production were low, ca $18.0 \mathrm{mg} \mathrm{chl}$ a $\mathrm{m}^{-2}$ and $150 \mathrm{mg} \mathrm{C} \mathrm{m}^{-2} \mathrm{~d}^{-1}$ respectively (Fig. 4a). These levels fall within the range of values for the spring phytoplankton bloom and post-bloom conditions in the LSLE (Levasseur et al. 1984. Therriault \& Levasseur 1985, Vézina 1994, Vézina et al. 1995, Savenkoff et al. 1997). 


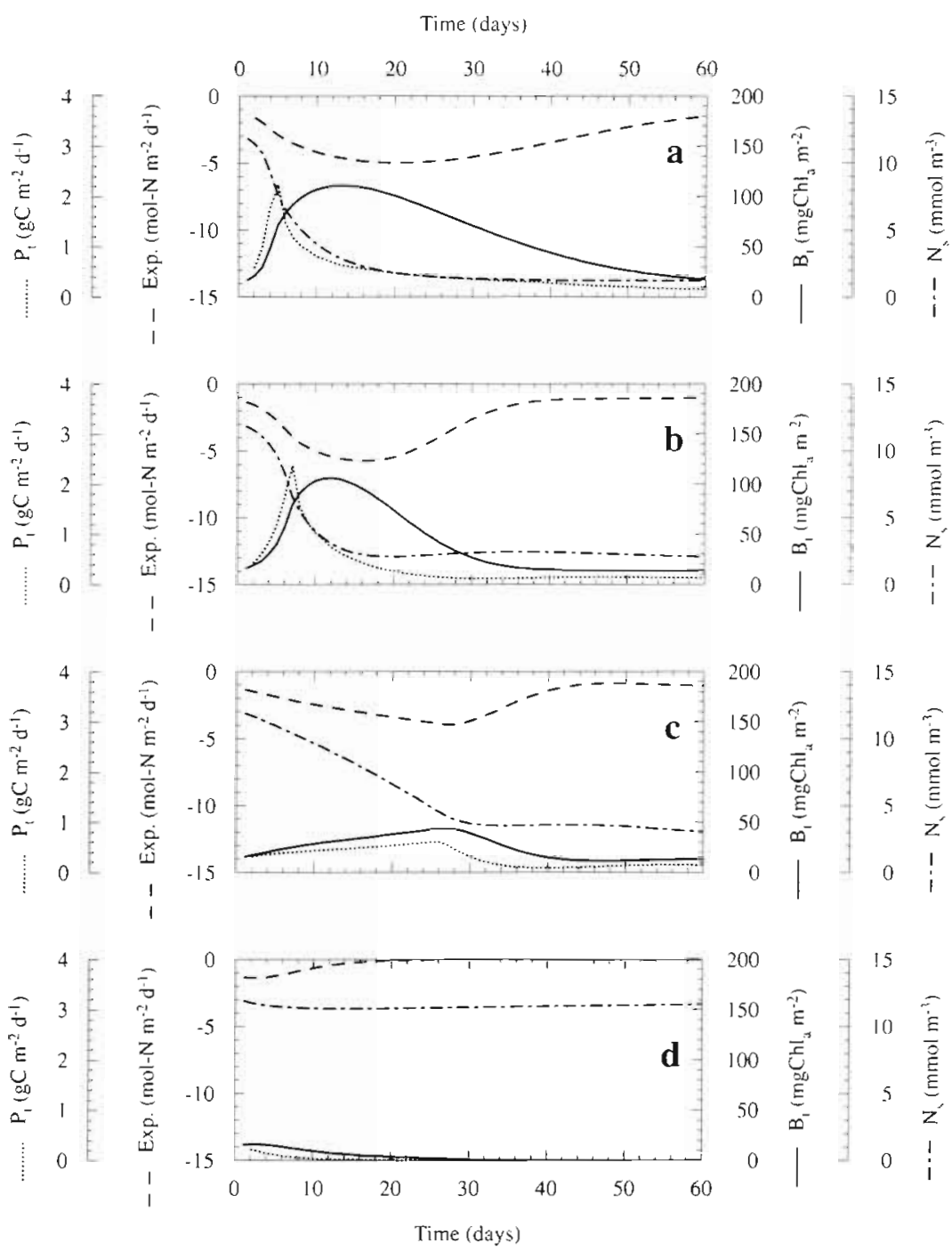

Fig. 4. Temporal evolution of depth-integrated primary production $\left(P_{f,} 0-15 \mathrm{~m}\right)$, chl a biomass $(0-15 \mathrm{~m})$ and exported production (Exp., $0-150 \mathrm{~m}$ ) and surface nutrients $\left(N_{\mathrm{s}}=\mathrm{NO}_{3}+\mathrm{NH}_{4}\right.$ averaged over the euphotic zone) for the $60 \mathrm{~d}$ simulations made with a low TKE dissipation rate $\left(\varepsilon=5.0 \times 10^{-8} \mathrm{~m}^{2} \mathrm{~s}^{-3}\right)$ and phytoplankton sinking rates of (a) 0 , (b) 1 , (c) 2 and (d) $3 \mathrm{~m} \mathrm{~d}^{-1}$

ent, light and stratification conditions prevailing before and during the COUPPB-90 experiment are favorable for a rapid bloom which would affect the whole LSLE.

\section{Vertical turbulent mixing versus sinking}

Application of higher values for the TKE dissipation rate $\left(\varepsilon \approx 1\right.$ to $\left.5 \times 10^{-7} \mathrm{~m}^{2} \mathrm{~s}^{-3}\right)$ did not significantly change the temporal evolution of the phytoplankton bloom. The bloom developed more slowly (less than $10 \mathrm{~d}$ ) but yielded higher maximum and steady-state primary production and phytoplankton biomass (Fig. 5a). The computed depth-integrated phytoplankton biomass and production remained typical of a phytoplankton coastal or estuarine bloom (170 $\mathrm{mg} \mathrm{chl} \mathrm{a} \mathrm{m}^{-2}$ and $3.5 \mathrm{~g} \mathrm{C}$ $\mathrm{m}^{-2} \mathrm{~d}^{-1}$ ). The surface layer was rapidly and permanently depleted of nutrients, while the vertical distribution of phytoplankton biomass did not show subsurface maxima as in the preceding simulation (Fig. 6). This indicates that vertical turbulent mixing, under the stratification conditions imposed in the simulation, is not a limiting factor for phytoplankton growth, i.e. there is not sufficient turbulent leakage of phytoplankton cells out of the euphotic zone in the sense described by Lucas et al. (1998).

In contrast, phytoplankton cell sinking has a more pronounced effect on the dynamics of phytoplankton. With a sinking rate of $1 \mathrm{~m} \mathrm{~d}^{-1}$, the bloom was delayed slightly and yielded maximum values for depth-integrated new production

The lag between the primary production and biomass maxima (Fig. 4 a) is related in part to the imposition of constant grazing pressure, which uncouples changes in phytoplankton and grazer biomass. The lag is also related to regeneration processes that acted to retain some of the previously assimilated nitrogen in the surface layer. Note that the time scale of mesozooplankton population dynamics (typically 2 to $3 \mathrm{wk}$ ) is greater than the $1 \mathrm{wk}$ lag between the higher primary production and higher phytoplankton biomass. Thus, except for the final stage, which did not include a response of grazer populations, this temporal sequence is typical of the train of events during a phytoplankton bloom. This first simulation shows that standard nutri- and phytoplankton biomass similar to those in the preceding simulation run with the same $\varepsilon$ value. Phytoplankton biomass decreased faster after the bloom and was lower in the steady-state solution (Fig. 4b). Fig. 6 shows the rapid sinking of the DCM formed during the bloom. With a sinking rate of $2 \mathrm{~m} \mathrm{~d}^{-1}$, the temporal changes in integrated phytoplankton biomass, primary production and export were greatly reduced. Maxi-

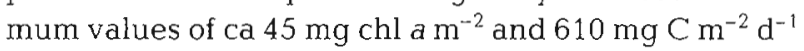
for phytoplankton biomass and primary production were reached after $26 \mathrm{~d}$ (Fig. 4c). Nutrients in the surface layer slowly decreased during the first half of the simulation but were not totally depleted after $60 \mathrm{~d}$. Under low vertical turbulent mixing conditions, a $3 \mathrm{~m}$ 


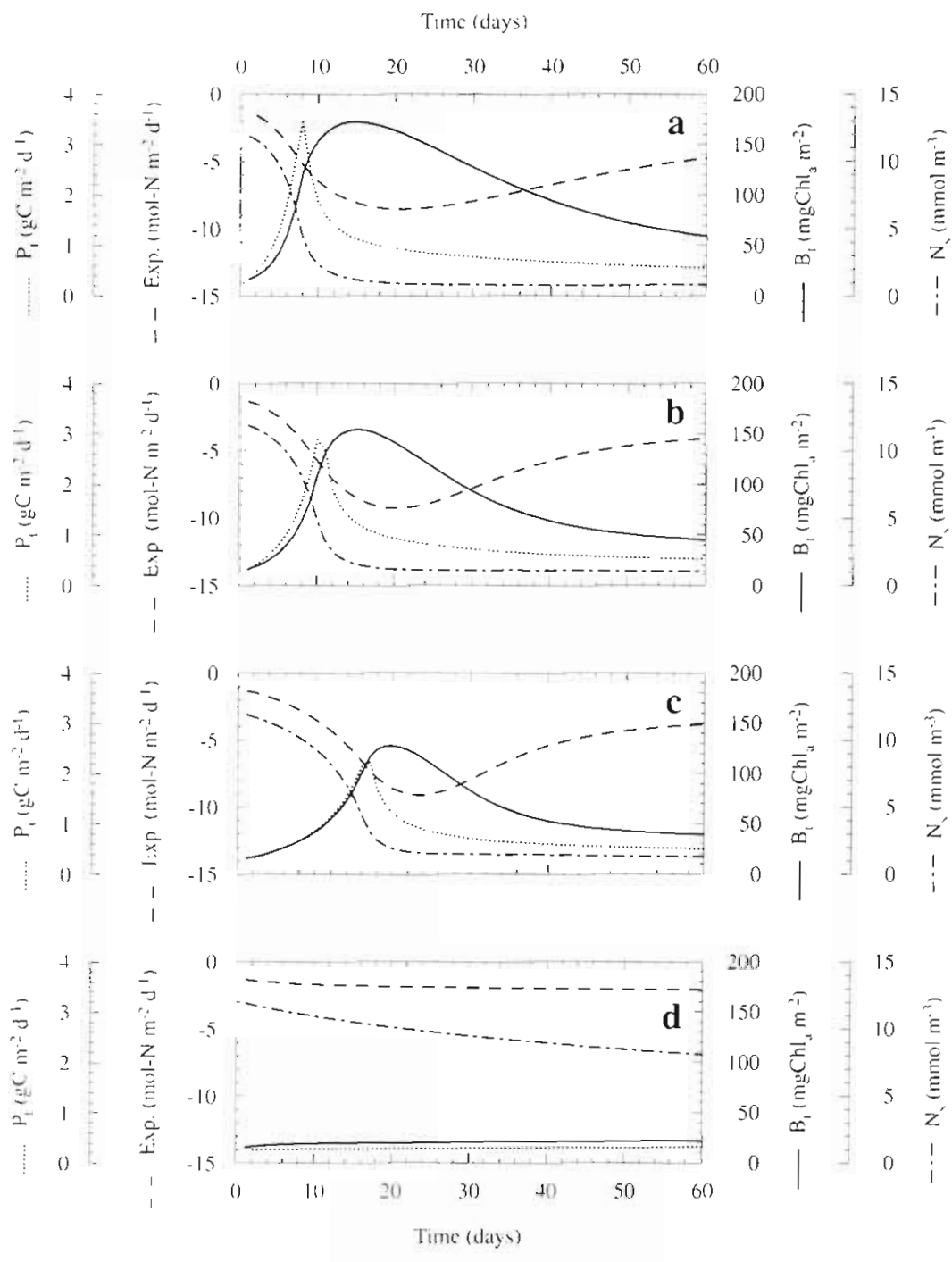

Fig. 5. Temporal evolution of depth-integrated primary production $\left(P_{t}, 0-15 \mathrm{~m}\right)$, chl a biomass $(0-15 \mathrm{~m})$ and exported production (Exp., $0-150 \mathrm{~m}$ ) and surface nutrients $\left\{N_{5}=\mathrm{NO}_{3}+\mathrm{NH}_{4}\right.$ averaged over the euphotic zone $\}$ for the $60 \mathrm{~d}$ simulations made with a high TKE dissipation rate $\left(\varepsilon=5.0 \times 10^{-7} \mathrm{~m}^{2} \mathrm{~s}^{-3}\right)$ and phytoplankton sinking rates of (a) 0, (b) 1, (c) 2 and (d) $3 \mathrm{~m} \mathrm{~d}^{-1}$ sinking rate was greater than $2 \mathrm{~m} \mathrm{~d}^{-1}$, i.e. no bloom was simulated under such conditions. Note the Iong delay (more than 15 d) before the onset of the phytoplankton bloom under conditions of high vertical turbulence and a $2 \mathrm{~m} \mathrm{~d}^{-1}$ sinking rate (Fig. 5c). Lastly, the lag between primary production and phytoplankton biomass maxima was reduced as the sinking rate increased (Figs. $4 b, c \& 5 b, c$ ). This is because sinking removed phytoplankton biomass from the euphotic zone and allowed more regeneration at depth, i.e. below the euphotic zone.

\section{Flushing by the freshwater runofi: a 2-D approach}

Results of the 2-D simulation using the observed baroclinic velocity profiles at Stn 23 (Fig. 2c) are shown in Fig. 7. The simulated phytoplankton-nutrient system rapidly achieved a steady state (in less than 5 d) that generated slightly increasing phytoplankton biomass (from 14 to $46 \mathrm{mg} \mathrm{chl} \mathrm{a} \mathrm{m}^{-2}$ ) and slightly decreasing surface nutrient concentration in the downstream portion (150 to $200 \mathrm{~km}$ ) of the simulated area. The rapid steady state achieved in the 2-D simulations results from the residence time of phytoplankton biomass in the simulated area, i.e. the phytoplankton-nutrient system developed up to time $t=(200 \mathrm{~km}) / U_{\mathrm{s}}$ (approximately $4 \mathrm{~d}$ for the corresponding 1-D simulation). Depth-integrated primary production showed a similar but more pronounced seaward increase with maximum values ca $2.3 \mathrm{~g} \mathrm{C} \mathrm{m}^{-2} \mathrm{~d}^{-1}$ at the downstream boundary of the simulated area.

$\mathrm{d}^{-1}$ sinking rate removed all the phytoplankton biomass in less than $30 \mathrm{~d}$ (Fig. 4d).

A stronger vertical turbulent regime (larger $\varepsilon$ ) restored the bloom at a sinking rate of $2 \mathrm{~m} \mathrm{~d}^{-1}$ (Fig. 5c) and led to constant low phytoplankton biomass and primary production at higher sinking rates (Fig. 5d). This is because vertical turbulent mixing can partially oppose sinking by redistituuting phytoplanktion cells in the euphotic layer (see Fig. 6). This result agrees with the Lagrangian study of Lande \& Wood (1987) and the shallow estuary case described by Lucas et al. (19981. Nevertheless, values of phytoplankton biomass, primary production and nitrogen nutrients were not representative of a phytoplankton bloom when the
The simulation made using half the observed baroclinic velocity ( $U=1 / 2 U_{\text {mes }}$ ) led to a slower attainment of steady state (in appioximately $10 \mathrm{~d}$ ) with more marked seaward increases in phytoplankton biomass and decreases in surface nutrient concentrations in the downstream half of the section (Fig. 8). The depth-integrated primary production shows a zone of maximum values (ca $\left.2.8 \mathrm{~g} \mathrm{Cm}^{-2} \mathrm{a}^{-1}\right) 110$ lini downstreanit which corresponds to the beginning of the nutrient-impoverished area. In contrast, the maximum values for depthintegrated biomass, of ca $100 \mathrm{mg} \mathrm{chl} \mathrm{a} \mathrm{m}^{-2}$, were still at the end of the simulated estuary.

This spatial uncoupling between primary production and maximum phytoplankton biomass was partly due 


$$
\varepsilon\left(\mathbf{m}^{2} \mathbf{s}^{-3}\right)
$$
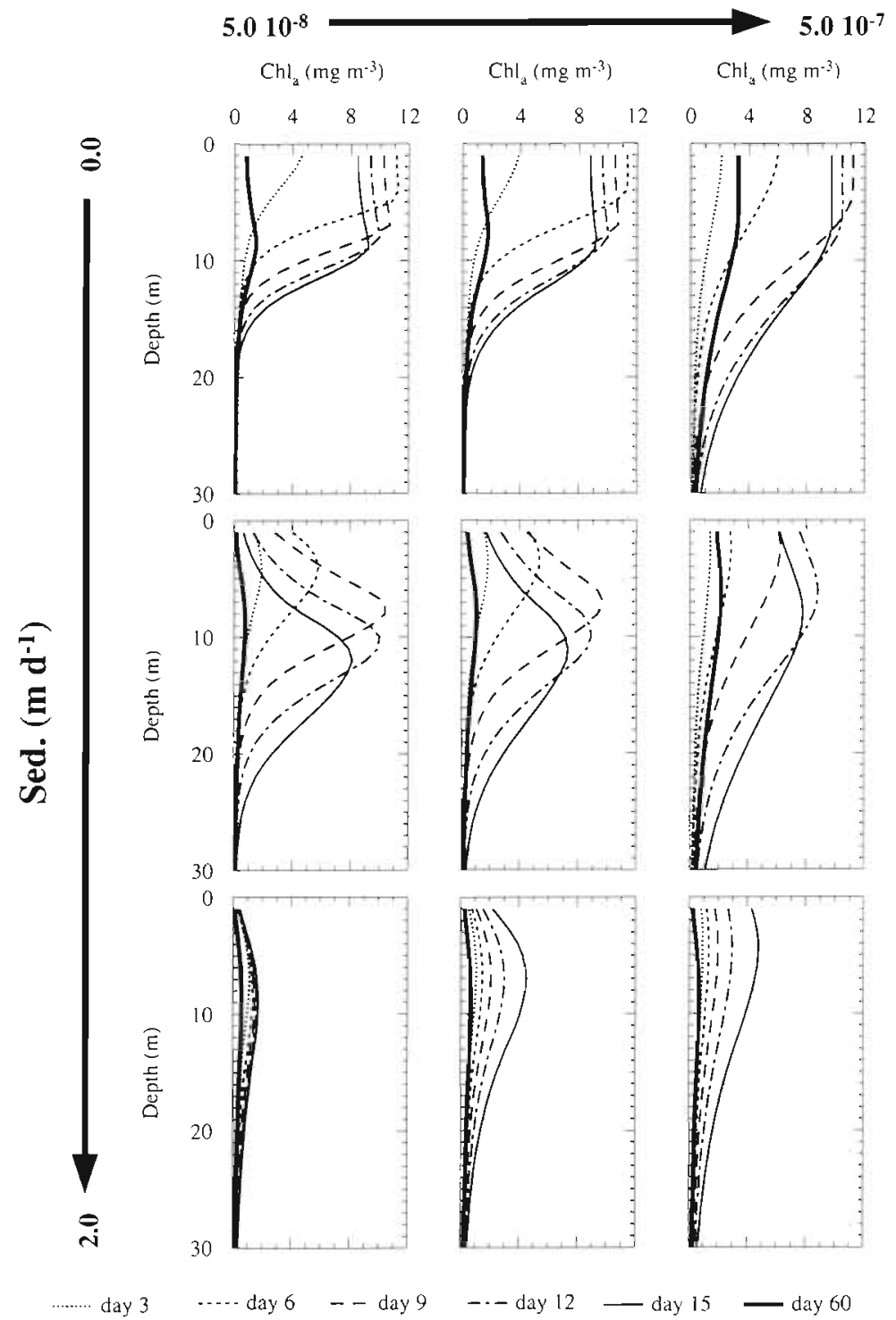

Fig. 6. Temporal evolution of the simulated vertical profiles of phytoplankton biomass for the first $15 \mathrm{~d}$ and for various regimes of vertical turbulent mixing ( $\varepsilon$ ranging from $5.0 \times 10^{-8}$ to $5.0 \times 10^{-7} \mathrm{~m}^{3} \mathrm{~s}^{-1}$ ) and sinking rates (Sed. varying from 0 to $2 \mathrm{~m} \mathrm{~d}^{-1}$ ); bold solid line in each panel: quasi steady-state vertical profile after $60 \mathrm{~d}$

to the temporal lag previously described in the 1-D simulation (e.g. Fig. 4a), which appears as a spatial uncoupling due to the advection of the whole phytoplankton-nutrient system. Note that the time needed to achieve the larger primary production rates in the 1-D simulation was ca $5 \mathrm{~d}$, which corresponds to a distance of $130 \mathrm{~km}$, close to the highest primary production zone in Fig. 8. Nevertheless, the depth-integrated daily assimilation ratios (as an index of these biomassproduction uncouplings) were nearly twice as large in the 2-D simulation [ca $56 \mathrm{~g} \mathrm{C}(\mathrm{g} \mathrm{chl} a)^{-1} \mathrm{~d}^{-1}$ in the high- est primary production zone with $U=1 / 2 U_{\text {mes }}$ l than in the 1 -D standard simulation [ca $32 \mathrm{~g} \mathrm{C}$ ( $\mathrm{g} \mathrm{chl} \mathrm{a})^{-1} \mathrm{~d}^{-1}$ at the time of highest primary production]. This implies that this spatial uncoupling also resulted partly from rapid advection of the phytoplankton biomass out of the high primary production zone.

\section{Comparisons with the COUPPB-90 observations}

Fig. 9 shows the depth-integrated (0 to $15 \mathrm{~m}$ ) phytoplankton biomass along the COUPPB-90 area from Legs G2 to G4. Note first the consistently low phytoplankton biomass upstream and a general tendency to a downstream increase in agreement with the 2-D simulations. For Leg $\mathrm{G} 2$, the along-shore increase is small and, except for 3 near-shore stations, bloom-like biomasses are restricted to the last third of the area. For Leg G3, the data suggest a biomass maximum near the middle of the section, while phytoplankton biomass remains high downstream. This maximum probably reflects the influence of the strong transverse current described by Savenkoff et al. (1997). This transverse current reduces the downstream residual advection and may allow the bloom to build up farther upstream. Leg G4 shows a similar tendency as Leg G3, but with a higher spatial variability. The more complex circulation patterns observed during Leg G4 are likely to explain this higher variability about the trend expected from the model simulations. The COUPPB-90 area starts $70 \mathrm{~km}$ downstream of the head of the Laurentian Channel and is $70 \mathrm{~km}$ long. Observed values are well bounded by the simulated depth-integrated biomass between 70 and $140 \mathrm{~km}$ for seaward advections of ca 0.3 to $0.6 \mathrm{~m} \mathrm{~s}^{-1}$ (Fig. 9).

The along-channel variability of the vertical profiles of chl a (Fig. 10) confirms the above findings but we noted the rapid occurrence of DCMs as the bloom develops downstream. Figs. 5 to 7 in Savenkoff et al. (1997) show that the surface inflow from the Gulf was negligible during COUPPB-90, so that the observed patterns in the vertical profiles of chl a would have been produced locally. Such DCMs can originate from 2 main processes: (1) increase at depth of the $\mathrm{chl} a / \mathrm{C}$ ratio due to adaptation to low light and (2) development of a deep biomass maxima following the nutrient impoverishment of the surface layer. The first process is unlikely to occur in shallow and turbulent euphotic layers as is the case here. The second process is the long-term normal out- 

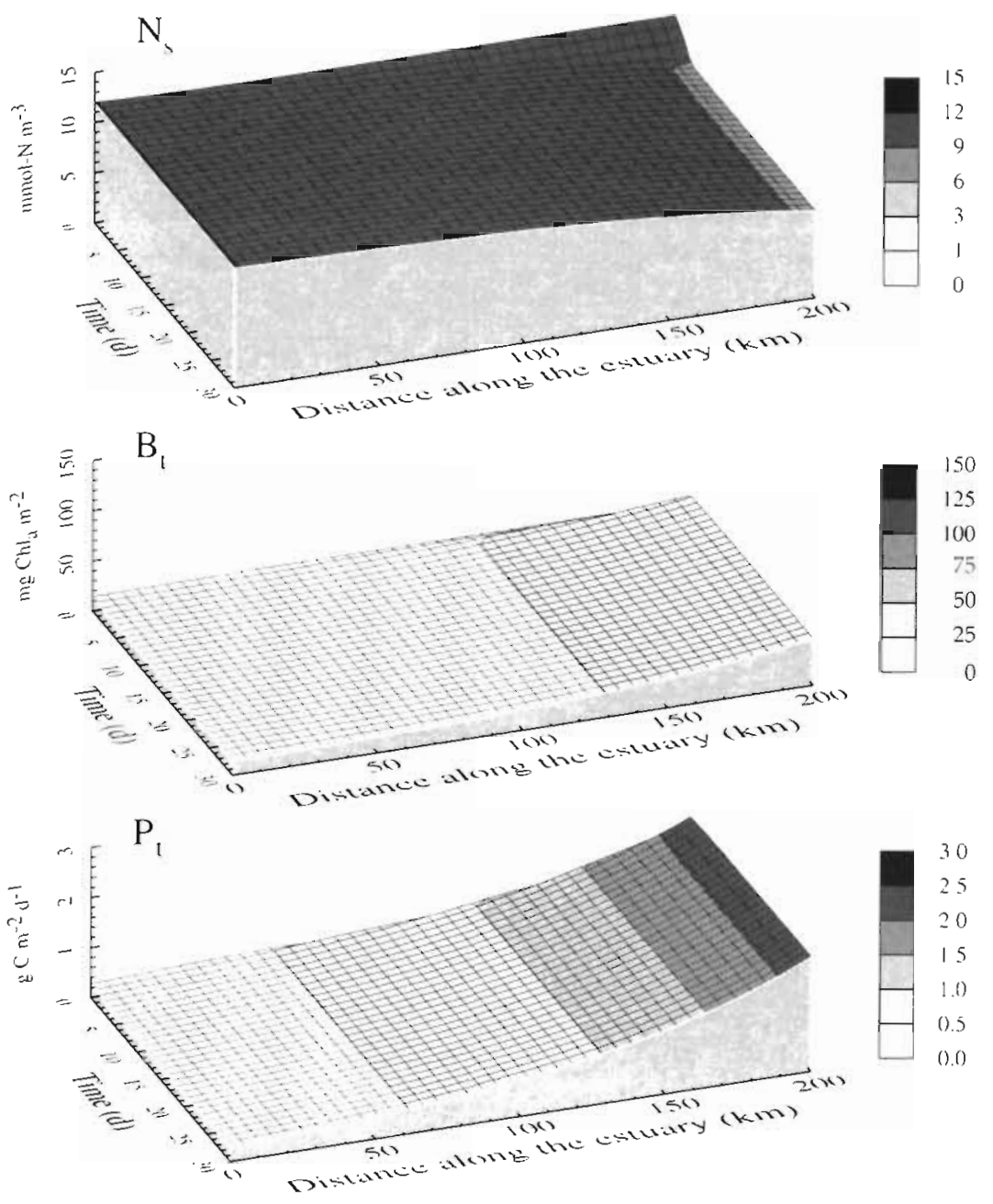

Fig. 7. Temporal evolution along the simulated estuary of surface nutrients $\left(N_{s}=\mathrm{NO}_{3}+\mathrm{NH}_{4}\right.$ averaged ovei the euphotic zone), depth-integrated phytoplankton biomoss $\left(B_{t}\right)$ and primary production $\left(P_{i}\right)$ obtained with the baroclinic velocity profile observed at Stn 23 (maximum surface current of ca $0.6 \mathrm{~m} \mathrm{~s}^{-1}$ ) during Leg $\mathrm{G} 2$ of the COUPPB-90 experiment

In more detail, observed vertical profiles of chl a during Leg G2 (Fig. 10) may correspond to the simulated ones for the first 3 to $7 \mathrm{~d}$ of a non-or slowly sinking population $\left(w_{\mathrm{s}}=\mathrm{ca} 0\right.$ to $\left.1 \mathrm{~m} \mathrm{~d}^{-1}\right)$, coherent with a mean seaward advection of ca $0.25 \mathrm{~m} \mathrm{~s}^{-1}$ and higher (Fig. 11). For Leg G3, observed profiles at the end of the COUPPB-90 area are comparable to simulated ones for a slowly sinking population $\left(w_{\mathrm{s}}=1.5 \mathrm{~m} \mathrm{~d}^{-1}\right)$ of ca 4 to $8 \alpha^{3}$, leading to a corresponding seaward advection of ca $0.20 \mathrm{~m} \mathrm{~s}^{-1}$ (Figs 10 \& 11). For Leg G4, the same reasoning gives $10 \mathrm{~d}$ and higher for residence time and a corresponding seaward advection of ca $0.15 \mathrm{~m} \mathrm{~s}^{-1}$ (Figs. $10 \& 11$ ).

The approach we used cannot capture all the possible short-term and smallscale processes that may affect the phytoplankton distribution and lead to DCMs, such as a local divergence of the turbulent flux or near-inertial wave shears (e.g. Franks 1994), subduction of the chl a-rich layer due to cross-frontal secondary circulation or, as discussed by Savenkoff et al. (1997), overflow of light, nutrient-rich and low-chl a waters on chl a-rich, low-nutrient surface water, so that the simulated DCMs show some discrepancies with the observed ones. Nevertheless, our approach should be able to reproduce the long-term trends of phytoplankton dynamics (e.g Zakardjian \& Prieur 1994). Moreover, the general tendency of the DCM to deepen from Legs $\mathrm{G} 2$ to $\mathrm{G} 4$ agrees with the scenario of a slowly sinking population, and the persistence of low chloro-

come of the bloom but it is more rapid for slowly sinking cells (Fig. 6). Hence, to perform comparisons with the simulated vertical profiles, we have to define a mean residence time for the phytoplankton biomass in the COUPPB-90 area. Estimating a mean seaward advection is difficult due to the rapid changes in the COUPPB-90 observed circulation patterns. However, Savenkoff et al. (1997) estimated the velocity of the pulse-like feature which led to this circulation variability to be ca $0.15 \mathrm{~m} \mathrm{~s}^{-1}$. Taking thic value as a background seaward velocity leads to a residence time of $5.5 \mathrm{~d}$ in the COUPPB-90 area and $11 \mathrm{~d}$ if we include the distance from the head of the Laurentian Channel. It can be seen from Fig. 6 that only a slowly sinking phytoplankton population may be able to produce DCMs in such short times. phyll values in the upstream part of the COUPPB-90 area (Figs. 9 \& 10) agrees with the flushing scenario. Hence, the residence time of the surface waters and the simulated bloom development time match sufficiently well to explain the along-channel patterns in phytoplankton biomass observed during the COUPPB90 experiment.

\section{DISCUSSION}

\section{The turbulent mixing hypothesis}

Results presented in this study proceed fiom a series of numerical tests of physical processes which may affect the timing and spatial location of the phyto- 

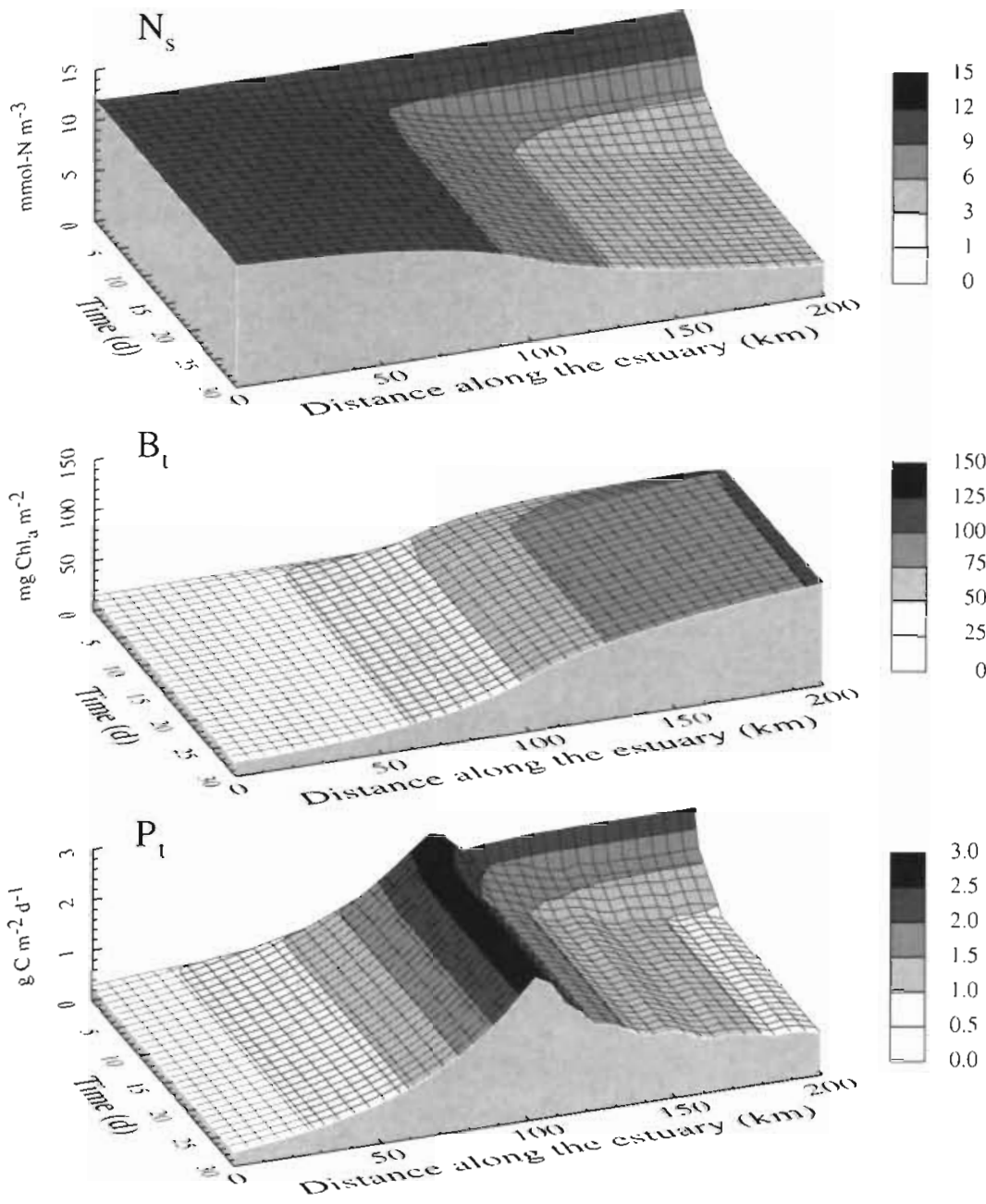

Fig. 8. Temporal evolution along the simulated estuary of surface nutrients $\left(N_{s}=\mathrm{NO}_{3}+\mathrm{NH}_{4}\right.$ averaged over the euphotic zone), depth-integrated phytoplankton biomass $\left(B_{t}\right)$ and primary production $\left(P_{l}\right)$ obtained with a 2 -fold weaker baroclinic velocity profile than that observed (maximum surface current of ca $0.3 \mathrm{~m} \mathrm{~s}^{-1}$ )

plankton bloom in the LSLE. The first process is related to vertical turbulent mixing, which affects light and nutrients conditions as well as the vertical distribution of the phytoplankton cells in the light and nutrient gradients. The effect of turbulent mixing on nutrient supply is negligible for the onset of the bloom as nutrients are generally abundant after winter mixing. For a stratified euphotic zone, as in the LSLE, the effect of vertical turbulent mixing on the light conditions can be estimated by comparison of the time scale $t_{\text {om }}=1 /\left(2 K_{z} \chi^{2}\right)$, which compares the time to mix through 1 optical depth with the doubling time in carbon biomass $t_{c}$, as a function of light limitation (e.g. Prieur \& Legendre 1988). When $t_{\mathrm{om}}$ is less than $t_{\mathrm{c}}$ vertical turbulent mixing affects the light conditions experienced by phytoplankton in a way that decreases $t_{c}$, i.e. the cells receive a larger amount of light due to the non-linear
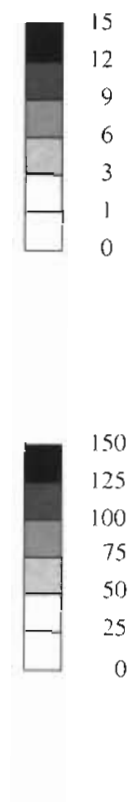

change of irradiance with depth. The effect then favors phytoplankton growth and, as we are searching for factors that limit the bloom, does not need to be considered further.

Lucas et al. (1998) have shown that, for shallow estuaries $(0$ to $20 \mathrm{~m}$ ), the main effect of vertical mixing on phytoplankton blooms is through turbulent leakage of phytoplankton cells out of the euphotic layer. In this study we tested the effect of vertical turbulent mixing by varying $\varepsilon$ (the TKE dissipation rate) across the mean stratification observed in the LSLE in late spring and prior to the bloom. Our simulations have shown that high vertical turbulent mixing ( $\varepsilon$ up to $5.0 \times 10^{-7} \mathrm{~m}^{2} \mathrm{~s}^{-3}$ ) delays the bloom by only 5 to $10 \mathrm{~d}$ and, moreover, increased new production and phytoplankton biomass computed by the model. It appears then that the increase in stratification from Legs G2 to G4 (see Savenkoff et al. 1997), and increased stability of the water column, would not be the sole factor responsible for the timing of the bloom. None of these stratification regimes limits phytoplankton growth as the model shows that there is insufficient turbulent leakage of phytoplankton cells out of the euphotic zone even with the least stratified regime (Leg G2) and with high TKE dissipation rates. Note that in the LSLE the spring to early summer changes in stratification are mainly dependent on salinity changes, hence driven by the spring freshet, so that the stratification regime tested here may have prevailed for several weeks before the COUPPB-90 experiment.

\section{The sinking hypothesis}

Our simulations indicate that phytoplankton cell sinking is a factor that may limit phytoplankton growth in the LSLE. Species that form the bulk of the phytoplankton bloom in July are mainly diatoms of Thalassiosira, Nitzschia, Skeletonema and Chaetoceros (Levasseur et al. 1984, Sime-Ngando et al. 1995, Savenkoff et al. 1997). Smayda (1970) reported mean values of sinking rate for actively growing individual cells of less than $2 \mathrm{~m} \mathrm{~d}^{-1}$ for these genera, while sinking rates greater than $2 \mathrm{~m} \mathrm{~d}^{-1}$ would be more relevant for senescent cells. In our simulations, the sinking rate of $2 \mathrm{~m} \mathrm{~d}^{-1}$ 

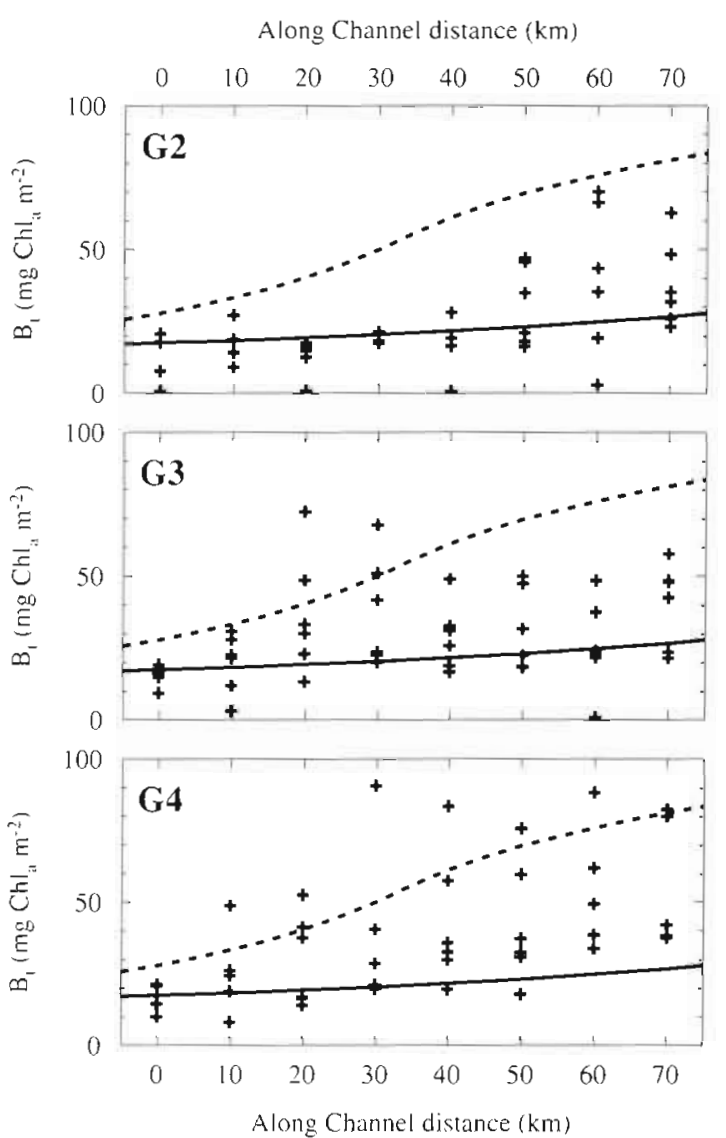

Fig. 9. Depth-integrated (0 to $15 \mathrm{~m}$ ) phytoplankton biomass in the along-channel direction for the 3 legs, G2 to G4, of the COUPPB-90 experiment; the section starts ( $\mathrm{km}$ 0) at Stns 43 to 48 in Fig. 1; solid and dashed lines: steady-state depth-integrated phytoplankton biomass extracted from the simulations using the observed and 2 -fold weaker baroclinic velocity profiles, respectively, considering that the COUPPB-90 area begins $70 \mathrm{~km}$ downstream of the simulated area

is a critical threshold since phytoplankton biomass decreased rapidly for higher sinking rates. Indeed, the euphotic zone is typically 10 to $15 \mathrm{~m}$ deep in the LSLE, due to the high turbidity of the freshwater from the St. Lawrence, Saguenay and Manicouagan-Bersimis-Aux Outardes rivers. With a sinking rate of $2 \mathrm{~m} \mathrm{~d}^{-1}$, the time for 1 phytoplankton cell to sink through the euphotic layer is close to the minimum time scale of the bloom ( 5 to $6 \mathrm{~d}$ ). Obviously, sinking rates of $2 \mathrm{~m} \mathrm{~d}^{-1}$ and more may have a more dramatic effect on the phytoplankton dynamics than vertical turbulent mixing.

This reasoning considers that only individual cells

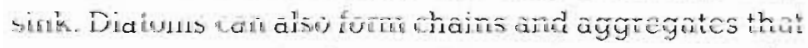
can sink at speeds of several tens of meters per day (e.g. Smayda 1970, Alldredge \& Jackson 1995). However, it is unlikely that the bloom could develop in the thin euphotic layer of the LSLE with such high sinking rates. This agrees with the finding that flocculation and aggregation occur largely after the bloom maximum.
Finally, inclusion of phytoplankton cell sinking in the 1-D model can lead to stationary low phytoplankton biomass under high-nutrient, high-light conditions (e.g. Fig. 5d). While such a steady state may account for the absence of blooms, as observed during Leg G2, it would not explain why the phytoplankton bloomed $10 \mathrm{~d}$ later, in a period during which the limiting effect of sinking would become increasingly important, as stratification increases from Legs G2 to G4. Limitation of phytoplankton dynamics by sinking is then unable to explain the 2 mo delay of the LSLE bloom.

\section{The flushing hypothesis}

As other hypotheses cannot account for the delay of the spring phytoplankton bloom in the LSLE, we must consider the effect of the seaward component of the buoyancy-induced current linked to the freshwater runoff of the St. Lawrence and Saguenay rivers. Our 2-D simulations show that a residual, seaward surface advection of $0.6 \mathrm{~m} \mathrm{~s}^{-1}$ prevents biomass accumulation along a distance equivalent to the length of the LSLE. Imposing a similar but $50 \%$ weaker baroclinic velocity profile resulted in a situation where only the second half of the simulated area showed the characteristics of a phytoplankton bloom, a situation which compares well with observations made during the COUPPB-90 experiment.

The 2-D simulations described here were done with the standard parameter set defined in the 1-D simulations, which assumed a low TKE dissipation rate and no phytoplankton cell sinking. This represents the shortest time scale for the simulated phytoplankton bloom (e.g. Figs. 4 \& 5). Increasing the vertical turbulent regime or adding phytoplankton cell sinking lengthens the bloom time scale and, consequently, increases the limiting effect of seaward surface advection on phytoplankton biomass accumulation. Comparisons with the COUPPB-90 data set suggest that the sinking rates of the diatom population were low during the 1990 bloom. The effect of such low sinking rate on a 1-D phytoplankton bloom is mainly a slight delay ( 2 to $3 \mathrm{~d}$ by comparison with the standard simulation, see Figs. $4 \mathrm{~b} \& 5 \mathrm{~b}$ ) but its effect can be much stronger when advection is considered. With a background seaward velocity of $15 \mathrm{~cm} \mathrm{~s}^{-1}$, this 2 to 3 d delay is equivalent to 25 to $40 \mathrm{~km}$, or approximately half the length of the COUPPB-90 area. In other words, this delay is of the samc order as the increased residence time in the COUPPB-90 area in response to a decrease in the seaward residual buoyancy-induced velocity from 20 to $15 \mathrm{~cm} \mathrm{~s}^{-1}$ (e.g. Fig. 11)

Due to this close match between the bloom development time and residence times in the LSLE, the seaward residual buoyancy-induced circulation is able to 


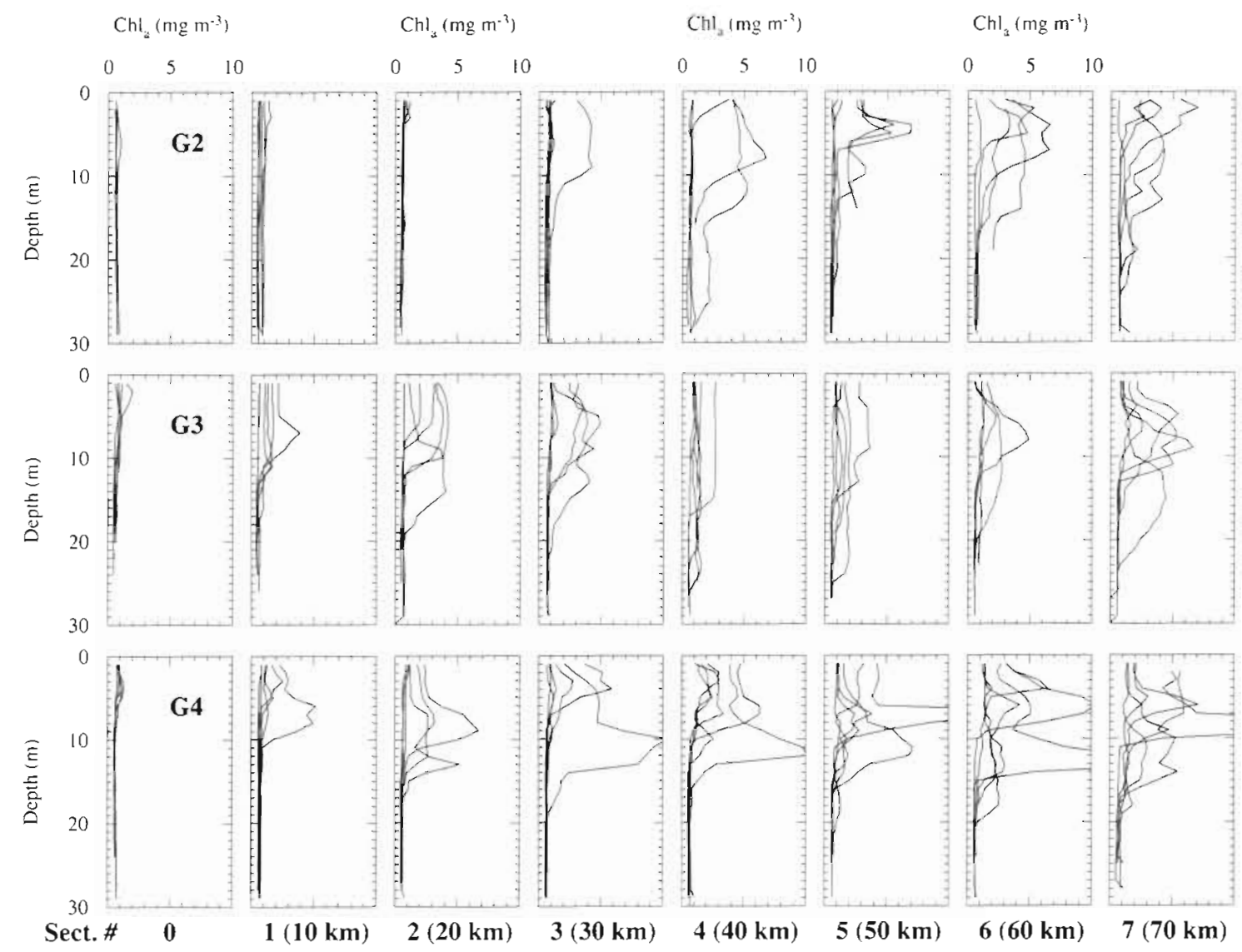

Fig. 10. Variability of the vertical profiles of chl $a$ in the along-channel direction during the 3 legs, G2 to G4, of the COUPPB-90 experiment; sections are numbered 0 to 7 and are spaced $10 \mathrm{~km}$ apart

prevent accumulation of phytoplankton biomass, but small changes in its velocity may trigger the onset of the bloom. The onset of the phytoplankton bloom in the LSLE generally coincides with the decrease in the freshwater runoff from the St. Lawrence and Saguenay rivers that occurs in late June/early July (Koutitonsky \& Bugden 1991), so that the subsequent decrease in seaward residual advection may determine the timing of the phytoplankton bloom in the LSLE. The bloom generally appears first in the downstream part of the LSLE and then propagates upstream (e.g. Therriault \& Levasseur 1985), a train of events which agrees with the flushed euphotic zone hypothesis. CZCS (Coastal Zone Color Scanner) imagery of the gulf and the estuary has shown that discharge of the St. Lawrence and Saguenay rivers and their fluctuations are involved in the spatio-temporal variability of phytoplankton abundance in the LSLE and Northwest Gulf (Fuentes-Yaco et al. 1997). Trites \& Drinkwater (1991) reported toxic algae blooms in the Western Gulf that would originate from the LSLE, suggesting that the buoyancy-induced seaward advection may limit phytoplankton accumulation in the estuary. Moreover, the role of transverse baroclinic currents at the onset of the phytoplankton bloom in the LSLE, as shown in Vézina et al. (1995) and Savenkoff et al. (1997), strengthens this flushing hypothesis.

\section{The role of other environmental factors}

The limiting effect of seaward advection depends on the ratio between the residence time of phytoplankton cells in the LSLE on the bloom time scale, i.e. the time scale of phytoplankton biomass development, and nutrient depletion which, in turn, depends on environmental conditions, such as light, temperature and vertical turbulent mixing, and on ecological conditions, such as grazing, regeneration and sinking. Any biological or physical process that lengthens the bloom development time will strengthen the flushing effect.

Here, temperature limitation of phytoplankton growth rate (Eppley 1972) is an important factor to consider when dealing with phytoplankton dynamics in subarctic areas such as the LSLE (e.g. Levasseur et al. 1984). The LSLE is known as a cold environment (e.g. Gratton 

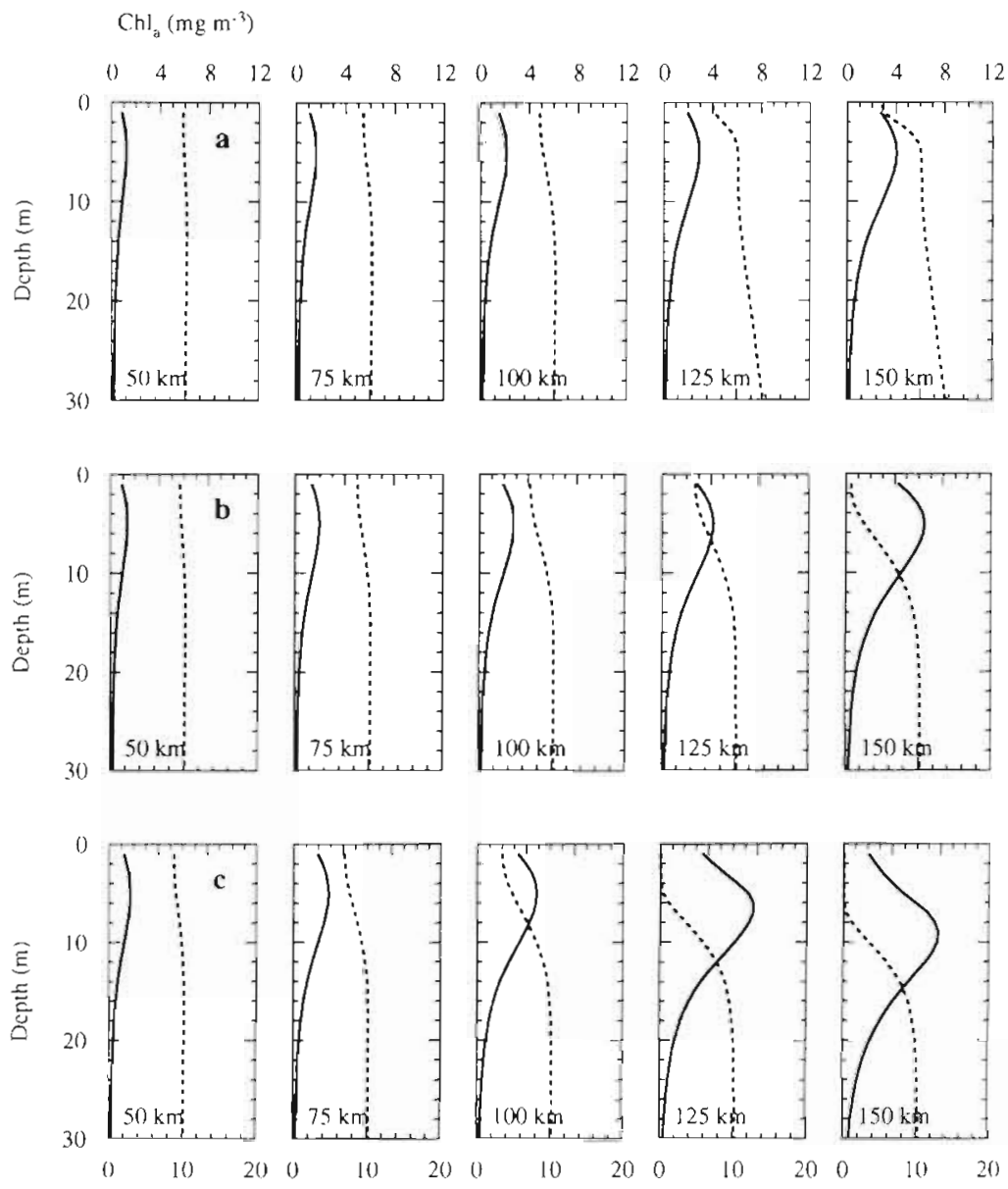

$\mathrm{NO}_{3}\left(\mathrm{mmol} \mathrm{m}^{-3}\right)$

Fig. 11 Steady-state vertical distrubutions of phytoplankton biomass las chl $a_{1}$ solid lines\} and nitrate $\left(\mathrm{NO}_{3}\right.$, dashed lines) at selected distances corresponding to the COUPPB-90 area for a slowly sinking population $\left(w_{2}=1.5 \mathrm{~m} \mathrm{~d}^{-1}\right)$ and barochinic velocity profiles of (a) $40 \%$ (surface velocity of ca $0.20 \mathrm{~m} \mathrm{~s}^{-1}$ ). (b) $30 \%$ (ca $0.25 \mathrm{~m} \mathrm{~s}^{-1}$ ), and (c) $25 \%\left(\mathrm{ca} 0.15 \mathrm{~m} \mathrm{~s}^{-1}\right.$ ) of the measured velocities
Legs $\mathrm{G} 2$ and $\mathrm{G} 4$ of the COUPPB-90 experiment was no more than $3^{\circ} \mathrm{C}$, and monthly mean temperatures computed by Petrie et al. (1996) for the LSLE show that the warming of the upper $15 \mathrm{~m}$ of the water column takes place from April to June, non-limiting surface temperature $\left(>5^{\circ} \mathrm{C}\right)$ being achieved during May. Hence, temperature limitation of phytoplankton growth rate is unable to explain the 2 mo delay of the bloom. Nevertheless, temperature limitation of phytoplankton growth rate may combine with the flushing during the earlier growing season (MarchApril) to prevent early blooms in the LSLE.

Likewise, we tested the effect of grazing on the bloom development time considering a 2-fold higher maximum grazing term, $G_{\text {max }}$. It can be seen from Fig. 12c that doubling the grazing pressure limits the development of the phytoplankton biomass but does not delay or prevent the bloom. Obviously, increasing grazing pressure further will remove enough phytoplankton biomass to lead to no-bloom conditions. To have an effect on the timing of the bloom, one may consider peculiar interactions between grazers and phytoplankton, i.e an initially grazing-limited phytoplankton biomass which blooms due to the removal of its grazers. Given the estuarine circulation in the LSLE, this would imply differential flushing of phytoplankton and their grazers. However, ciliates and adult females and young stages of the dominant herbivorous copepods are surface-dwelling organisms, hence subject to the same flushing as phytoplankton. et al. 1988) but winter or early spring diatom blooms have been reported in a low temperature environment $\left(<2^{\circ} \mathrm{C}\right)$ in North Allantic coastal waters by Hitchcock \& Srnayda (1977) and Townsend et al. (1994). Here, we tested the effect temperature limitation of phytoplankton growth rate has on the bloom development time with a simple 1 -D simulation using a 2 -fold higher minimum doubling time $t_{\text {dmin }}$, or equivalently a 2 -fold lower maximum growth rate, $\mu_{\max }$. It is not a true use of the Eppley (1972) relationship, rather a simple illustrathon of the possible cffcet of assuming growth ratos reduced by half due to very low temperatures.

Fig. $12 a, b$ compares the result of this simulation to the standard simulation. A lower $\mu_{\max }$ as the result of a temperature limitation of phytoplankton growth rate, leads to a 5 to 10 d delay of the bloom. Nevertheless, the increase in surface temperature observed between

\section{Comparisons with other estuarine systems}

Estuaries in which a late bloom is related to the spring-freshet-induced flushing of the surface layer estuaries are generally fjords which are deep and narrow (Sinclair et al. 1981). In a shallow well-mixed estuary, wind and tidal mixing have greater effects on phytoplankton dynamics, through either light conditions (e.g. Monbet 1992), leakage of phytoplankton cells out of the euphotic zone (Lucas et al. 1998) or socding of the water column by resuspension of resting spores (e.g. Haas et al. 1981), than the flushing of the surface layer. However, some examples of flushed phytoplankton bloom are reported in shallow estuarles, but for short time scales and generally for nanoplankton populations of the oligo- to mesohaline zones, as in the Neuse River Estuary in North Carolina 


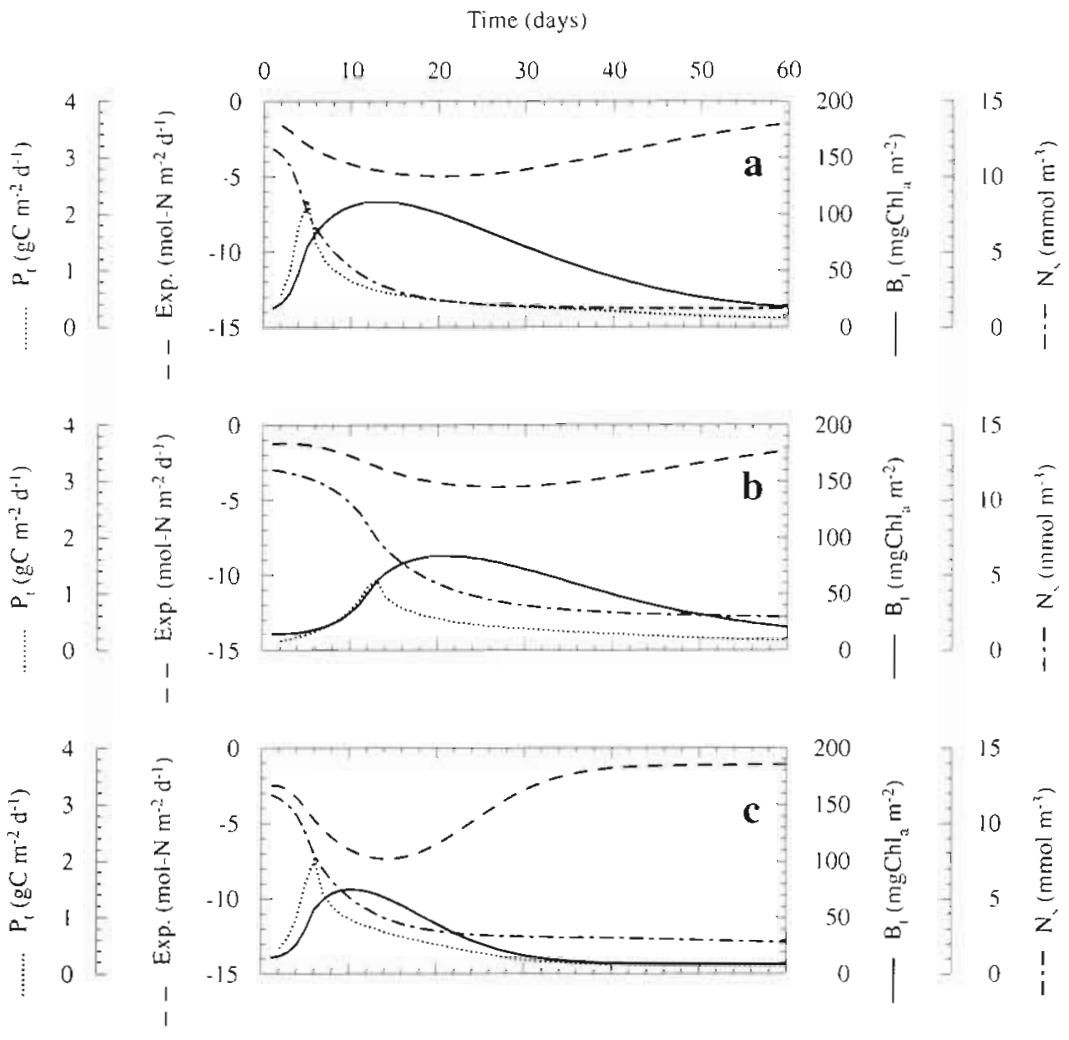

Fig. 12. Temporal evolution of depth-integrated primary production $\left(P_{t}, 0-15 \mathrm{~m}\right)_{1}$ chl a biomass $(0-15 \mathrm{~m})$ and exported production (Exp., $0-150 \mathrm{~m}$ ) and surface nutrients nutrients $\left(N_{5}=N_{3}+N_{4}\right.$ averaged over the euphotic zone) for (a) the $60 \mathrm{~d}$ standard simulation compared with (b) a temperature limitation of phytoplankton growth rate scenario and (c) a higher grazing pressure scenario (see text for the 2 scenarios)

(Boyer et al. 1993), the James River Estuary in Virginia (Moon 1990) or in the Lower Hudson Estuary (Malone et al. 1980). In addition, the differential timing of the spring bloom between the lower, medium and upper Chesapeake Bay reported by Glibert et al. (1995) may be interpreted as a limited flushing effect. Indeed, it is likely that short-term fluctuations of other environmental conditions, i.e. turbulent mixing, turbidity, etc. (e.g. Malone et al. 1980, Legendre et al. 1982, Harding 1994, Glibert et al. 1995), would mask the effect of flushing on phytoplankton dynamics in shallow stratified estuaries.

Sinclair et al. (1981) argued that a necessary condition for a marked flushing effect is the narrowness of the estuary, which prevents the establishment of transverse motions. Our simulations suggest that flushing can occur in wide estuaries as well. The characteristic buoyancy-induced coastal jet considered in our simulations would not act on the whole LSLE width, as it is restricted to a width of 1 or 2 internal Rossby radii (ca $10 \mathrm{~km}$ in the LSLE), which is only one-quarter to one-third of the Estuary. Moreover, strong variations of the LSLE general circulation patterns occur during the bloom period (late spring/early summer), including cyclonic or anticyclonic eddies which have been attributed to atmospheric events (e.g. Tee \& Lim 1987, Mertz et al. 1992) and freshwater wave-like or pulse-induced instabilities (Mertz et al. 1988, Koutitonsky et al. 1990), the latter now considered to be dominant (Ingram \& El-Sabh 1990).

Nevertheless, such mesoscale features would not prevent the flushing of the surface layer as long as their residence time in the area is less than the bloom development time. Savenkoff et al. (1997) estimated the seaward speed of the freshwater pulse that induced the onset of the 1990 bloom to be ca $0.15 \mathrm{~m} \mathrm{~s}^{-1}$. Little is known about these mesoscale features in the pre-bloom period, although it is reasonable to assume they have short residence times in the LSLE, since they would be advected with speeds equivalent to the mean seaward buoyancy-induced residual current $\left(\geq 0.3 \mathrm{~m} \mathrm{~s}^{-1}\right)$. Hence, by influencing both the flushing time and environmental conditions (temperature and turbulent mixing), the seasonal evolution of the buoyancy circulation induced by freshwater discharge from the St. Lawrence and Saguenay rivers is likely to be the main factor regulating phytoplankton blooms in the LSLE.

\section{General implications}

The seasonal evolution of light conditions in the upper layer has been recognized as the main factor regulating the primary production seasonal cycle for the whole estuary and gulf system (Levasseur et al. 1984, Therriault \& Levasseur 1985). The reasoning of Levasseur et al. (1984) was based on the SverdrupRiley critical depth model but it also appears from these studies that by April the light availability is not limiting phytoplankton growth in the LSLE. This indicates that the Sverdrup-Riley critical depth model sometime fails in estuarine systems, as shown by Lucas et al. (1998) in shallow estuaries. The Sverdrup-Riley model only gives necessary conditions for a phytoplankton bloom but, in its original mathematical form, cannot explain the delayed phytoplankton bloom in the LSLE: it only considers a simple loss term which stands for mean respiration and grazing, whereas sinking and physical loss terms are not included (e.g. Smetacek \& Passow 1990, Lucas et al. 1998). Physical 
loss terms would consider turbulent mixing and horizontal advection losses in the LSLE

The 2-D simulations also showed that seaward advection may spatially decouple zones of high phytoplankton biomass and new production at a mesoscale. This simple advective forcing can lead to spatial variability in the trophic characteristics of the ecosystem, which has important geochemical implications, for example, for the depth-integrated assimilation number or for the $f$-ratio. The use of such geochemical variables requires equilibrium of vertical fluxes through a laterally isolated (i.e. no lateral transport) water mass Vézina (1994) reported strong mesoscale variability in nitrogen uptake and the f-ratio during the 1989 bloom in the LSLE and showed that this assumption would not be valid during the phytoplankton bloom due to a lack of equilibrium between biomass increase and biomass export out of the euphotic zone. Earlier, Sinclair (1978) reported a lack of coherence in measured phytoplankton physiological state indices and questioned their utility.

As suggested by our simulations, such a lack of equilibrium may be partly explained by the advective effects on the phytoplankton-nitrogen system of new production that results in export of phytoplankton out of the localized high primary production zone. Vertical motions associated with geostrophic dynamics can induce similar spatial uncoupling at a small scale (Zakardjian \& Prieur 1998). Hence, the complex circulation patterns observed during the late spring bloom period can lead to strong small-and mesoscale heterogeneities of ecosystem characteristics that are difficult to interpret without taking into account the advective forcing of the ecosystem

\section{CONCLUDING REMARKS}

Physical-biological modeling allows the evaluation of the influence of hydrodynamic conditions on biological time scales as well as their matching with physical time scales. This study highlights the major role of flushing of the euphotic zone by freshwater runoff in the control of the timing of the phytoplankton bloom in the LSLE. This is due to a close match between the time scales of bloom development and flushing. Other environmental conditions, such as the vertical turbulent mixing regime (through stratification or TKE dissipaion salej, waies iusiulity and sinking of phytoplankton, affect the bloom development time and act in concert with advection to determine the timing, duration and intensity of blooms. An implication of this result is that interannual variation of the spring freshwater runoff may drive interannual variation in the dynamics of phytoplankton blooms in the LSLE. The simple 2-D simulations described here cannot, however, take into account the complex mesoscale features that occur in late spring in the LSLE. Given the possible biogeochemical implications of the strong influences of physical processes on primary production in the LSLE, particularly the spatial decoupling of phytoplankton biomass and primary production, a complete, coupled biological-physical 3-D study is warranted.

Acknowledgements. This work was supported by grants from the Natural Sciences and Engineering Research Council of Canada, Fisheries and Oceans Canada and the Ministère de l'Éducation du Québec through a postdoctoral grant to B.A.Z. (Programme Québecois de Bourse d'Excellence). Data were processed by C. Lafleur (CTD and ADCP data) and C. Savenkoff and $L$. Devine (biological and chemical data). We thank $J$. Runge very much for his comments and corrections on this manuscript. This is a contribution of the Groupe de Recherche en Environnement Côtier (GREC)

\section{LITERATURE CITED}

Alldredge AL, Jackson GA (1995) Aggregation in marine systems. Deep-Sea Res ll 42(1):1-7

Boyer JN, Christian RR, Stanley DW (1993) Patterns of phytoplankton primary productivity in the Neuse River estuary. Mar Ecol Prog Ser 97:287-297

de Lafontaine Y, Demers S, Runge JA (1991) Pelagic foodweb interactions and productivity in the Gulf of St. Lawrence: a perspective. In: Therriault JC (ed) The Gulf of St. Lawrence: small ocean or big estuary? Can Spec Publ Fish Aquat Sci 113:99-123

El-Sabh Ml (1979) The lower St. Lawrence estuary as a physical oceanographic system. Nat Can 106(1):55-73

Eppley RW (1972) Temperature and phytoplankton growth in the sea. Fish Bull US 60:1063-1085

Forrester WD (1.974) Internal tides in the St. Lawrence estuary. J Mar Res 32(1):55-66

Franks PJS (1994) Thin layers of phytoplankton: a model of formation by near-inertial wave shears. AGU/ASLO 1994 Ocean Sciences Meeting, EOS Spec Issue 75(3):O51D-4

Frost BW (1980) Chap 13, Grazing. In: Moriss I (ed) The physiologıcal ecology of phytoplankton. University of California Press, Berkeley, p 465-491

Fuentes-Yaco C, Vézina AF, Larouche P, Gratton Y, Gosselin $M(1997)$ Phytoplankton pigment in the Gulf of St. Law. rence Canada as determined by the Coastal Zone Color Scanner. Part II: multivariate analysis. Cont Shelf Res 17(12):1441-1459

Galbraith PS (1992) Relating overturns to mixing and buoyancy flux. PhD thesis, Dalhousie University, Halifax, NS

Glibert PM, Conley DJ, Fisher TR, Harding LW Jr, Malone TC (1995) Dynamics of the 1990 winter/spring bloom in Chesapeake Bay. Mar Ecol Prog Ser 122:27-43

Gratton Y, Mertz G, Gagne JA (1980) Satelite observations of tidal upwelling and mixing in the St. Lawrence Estuary. J Geophys Res 93(C6):6947-6954

Haas LW, Hasting SJ. Webb KL. (1981) Phytoplankton response to a stratification-mixing cycle in the York River estuary during late summer. In: Neilson BJ, Cronin LE leds) Estuaries and nutrients. Humana Press, Totowa, NJ. p $619-636$ 
Harding LW Jr (1994) Long-term trends in the distribution of phytoplankton in Chesapeake Bay: roles of light nutrients and stream-flow. Mar Ecol Prog Ser 104:267-291

Hitchcock GL, Smayda TL (1977) The importance of light in the initiation of the 1972-1973 winter-spring diatom bloom in Narraganset Bay. Limnol Oceanogr 22(1):126-131

Ingram RG. El-Sabh ML (1990) Fronts and mesoscale features in the St. Lawrence estuary. In: El-Sabh ML, Silverberg N (eds) Oceanography of a large-scale estuarine system: the St. Lawrence. Coast Estuar Stud 39:71-93

Jackson GA, Lochman SE (1992) Effect of coagulation on nutrient and light limitation of an algal bloom. Limnol Oceanogr 37(1):77-89

Kiørboe T (1989) Phytoplankton growth rate and nitrogen content: implications for feeding and fecundity in an herbivorous copepod. Mar Ecol Prog Ser 55:229-234

Koutitonsky VG, Bugden GL (1991) The physical oceanography of the gulf of St. Lawrence: a review with emphasis on the synoptic variability of the motion. In: Therriault $J C$ (ed) The Gulf of St. Lawrence: small ocean or big estuary? Can Spec Publ Fish Aquat Sci 113:57-90

Koutitonsky VG, Wilson RE, El-Sabh ML (1990) On the seasonal response of the lower St. Lawtence Estuary to buoyancy forcing by regulated river runoff. Estuar Coast Shelf Sci 31(4):359-379

Lande R, Wood AM (1987) Suspension times of particles in the upper ocean. Deep-Sea Res 34(1):61-72

Legendre L, Ingram RG, Simard Y (1982) Aperiodic changes of water column stability and phytoplankton in an Arctic coastal embayment Manitounuk Sound, Hudson Bay. Nat Can 109:775-786

Levasseur M. Therriault JC, Legendre L (1984) Hierarchical control of phytoplankton succession by physical factors. Mar Ecol Prog Ser 19(3):211-222

Lucas LV, Cloern JE, Koseff JR, Monismith SG, Thompson JK (1998) Does the Sverdrup critical depth model explain bloom dynamics in estuaries. J Mar Res 56(2):375-415

Malone TC, Neale PJ, Boardman D (1980) Influence of estuarine circulation on the distribution and biomass of phytoplankton size fractions. In: Kenedy VA (ed) Estuarine perspectives. Proceedings of the 5th Biennial International Estuarine Research Conference, Jekyll Island, Georgia, October 7-12, 1979. Academic Press, New York, p 249-262

Marsden RF, Gratton Y (1998) Surface pulses in the St. Lawrence Estuary. Atmos Ocean 36(3):271-295

Mertz G, El-Sabh ML, Proulx D. Condal AR (1988) Instability of a buoyancy-driven coastal jet: the Gaspé current and its St. Lawrence precursor. J Geophys Res 93(C6):6885-6894

Mertz G, Koutitonsky VG, Gratton Y, El-Sabh ML (1992) Wind-induced eddy motion in the Lower St. Lawrence Estuary. Estuar Coast Shelf Sci 34(6):543-556

Monbet Y (1992) Control of phytoplankton biomass in estuaries: a comparative analysis of microtidal and macrotidal estuaries. Estuaries 15:563-571

Moon CH (1990) Seasonal variation of phytoplankton biomass in the very low salinity region of the James River Estuary, Virginia, USA. Bull Korean Fish Soc 22(6):397-407

Ohman MD, Runge JA (1994) Sustained fecundity when phytoplankton resources are in short supply: omnivory by Calanus finmarchicus in the Gulf of St. Lawrence. Limnol Oceanogr 39(1):21-36

O'Neill RV, DeAngelis DL, Pastor JJ, Jackson BJ, Post WM (1989) Multiple nutrient limitations in ecological models. Ecol Model 46:147-163

Osborn TR (1980) Estimates of the local rate of vertical diffusion from dissipation measurements. J Phys Oceanogr 10(1):83-89
Petrie B, Drinkwater $K$, Sanström. A, Petipas R, Gregory D Gilbert D, Sekhon P (1996) Temperature salinity and sigma-t atlas for the Gulf of St. Lawrence. Can Tech Rep Hydrogr Ocean Sci 178

Pingree RD (1978) Mixing and stabilization of phytoplankton distributions on the Northwest European continental shelf. In: Steele JH (ed) Spatial pattern in plankton communities, Plenum Press, New York, p 181-220

Plourde S, Runge JA (1993) Reproduction of the planktonic copepod Calanus finmarchicus in the Lower St. Lawrence Estuary: relation to the cycle of phytoplankton production and evidence for a Calanus pump. Mar Ecol Prog Ser 102(3):217-227

Powell TM, Cloern JE, Huzzey LM (1989) Spatial and temporal variability in South San Francisco Bay (USA). 1 Horizontal distributions of salinity suspended sediments and phytoplankton biomass and production. Estuar Coast Shelf Sci 28(3):583-597

Prieur L, Legendre L (1988) Oceanographic criteria for new phytoplankton production. In: Rothschild BJ (ed) Toward a theory on biological-physical interactions in the World Ocean. Kluwer Academic Publishers, Boston, p 71-112

Roach PJ (1972) Computational fluid dynamics. Hermosa Publishers, Albuquerque, NM

Runge JA, Simard Y (1990) Zooplankton in the St. Lawrence Estuary: the imprint of physical processes on its composition and distribution. In: El-Sabh ML, Silverberg N (eds) Oceanography of a large-scale estuarine system: the St. Lawrence. Coast Estuar Stud 39:296-320

Savenkoff C, Vézina AF, Gratton Y (1997) Effect of freshwater pulse on mesoscale circulation and phytoplankton distribution in the lower St. Lawrence Estuary. J Mar Res 55(2): $353-381$

Sime-Ngando T, Gosselin M, Roy S, Chanut JP (1995) Significance of planktonic ciliated protozoa in the Lower St. Lawrence Estuary: comparison with bacterial phytoplankton and particulate organic carbon. Aquat Microb Ecol $9(3): 243-258$

Sinclair M (1978) Summer phytoplankton variability in the Lower St. Lawrence Estuary. J Fish Res Board Can 35(9): $1171-1185$

Sinclair M, Subba Rao DV, Couture R (1981) Phytoplankton temporal distributions in estuaries. Oceanol Acta 4(2):239-246

Smayda TJ (1970) The suspension and sinking of phytoplankton in the sea. Mar Biol Annu Rev 8:353-414

Smetacek V, Passow U (1990) Spring bloom initiation and Sverdrup's critical depth model. Limnol Oceanogr 35(1): $228-233$

Tee KT, Lim TH (1987) The freshwater pulse - a numerical model with application to the St. Lawrence estuary. J Mar Res 45(4):871-909

Therriault JC, Levasseur M (1985) Control of phytoplankton production in the lower St. Lawrence estuary: light and freshwater runoff. Nat Can 112(1):77-96

Therriault JC, Painchaud J, Levasseur M (1985) Factors controlling the occurrence of Protogonyaulax tamarensis and shellfish toxicity in the St. Lawrence estuary: freshwater runoff and the stability of the water column. In: Anderson DM, White AW, Baden DG (eds) Toxic dinoflagellates. Elsevier Science Publishing Co Inc, New York, p 141-146

Therriault JC, Legendre L, Demers S (1990) Oceanography and ecology of phytoplankton in the St. Lawrence estuary. In: El-Sabh ML, Silverberg $N$ (eds) Oceanography of a large-scale estuarine system: the St. Lawrence. Coast Estuar Stud 39:269-295

Townsend DW, Cammen LM, Holligan PM, Campbell DE, Pettigrew NR (1994) Causes and consequences of variabil- 
ity in the timing of spring phytoplankton bloom. Deep-Sea Res 41(5/6):747-765

Trites RW, Drinkwater KF (1991) The possible role of the surface circulation in the spread of PSP in the Western Gulf of St Lawrence in 1988. In: Therriault JC (ed) The gulf of St. Lawrence: small ocean or big estuary? Can Spec Publ Fish Aquat Sci 113:153-160

Vézina AF (1994) Mesoscale variability in nitrogen uptake rates and the f-ratio during a coastal phytoplanton bloom. Limnol Oceanogr 39(4):854-868

Vézina A.F, Gratton Y, Vinet P (1995) Mesoscale physical-biological varıability during a summer phytoplankton bloom

Editorial responsibulity: Fereidoun Rassoulzadegan, (Contributing Editor), Villefranche-sur-Mer, France in the lower St. Lawrence Estuary. Estuar Coast Shelf Sa $41(4): 393-411$

Wessel P, Smith WHF (1991) Free software helps map and display data. EOS Trans Am Geophys Union 72:441 445-446

Zakardjian B, Prieur L (1994) A numerical study of primary production related to vertical turbulent diffusion with special reference to vertical motions of the phytoplankton cells in nutrient and light fields. J Mar Syst 5(3-5):267--295

Zakardjian B. Prieur L (1998) Biological and chemical signs of upward motions in permanent geostrophic fronts of the Western Mediterranean. J Geophys Res 103(C12): $27849-27866$

Submitted: October 19, 1998; Accepted: July 5, 1999

Proofs received from author(s): January 24, 2000 